\title{
Our Criminal Law Should Only Be 200 Years Out of Date - and It Should Be Consolidated
}

\author{
Graham S McBain ${ }^{1,2}$ \\ ${ }^{1}$ Peterhouse, Cambridge, UK \\ ${ }^{2}$ Harvard Law School, USA \\ Correspondence: Graham S McBain, 21 Millmead Terrace, Guildford, Surrey, GU2 4AT, UK. E-mail: \\ gsmcbain@aol.com
}

Received: January 16, 2014 Accepted: April 8, 2014 Online Published: May 27, 2014

doi:10.5539/res.v6n2p120 URL: http://dx.doi.org/10.5539/res.v6n2p120

\begin{abstract}
In a modern democracy such as we have, it is essential that English law be up-to-date and relevant. However, much English law is out of date and obsolete. This is especially so in the field of criminal law. The purpose of this article is to argue for the repeal of many old pieces of English criminal legislation and for the consolidation of the remainder.
\end{abstract}

Keywords: criminal law, obsoletelegislation, repeal, consolidation

\section{Introduction}

We live in a modern society with a deepening democracy. One in which the State is expected to justify - and is increasingly held accountable for - the proper expenditure of large sums of taxpayers' money. We also live in a society where the general public expects the legal system - and the law - to be modern and up-to-date; not one that reflects the mores - and an imbalance of power in favour of the State - which existed centuries ago. After all, the public are paying for the legal system - the courts and the judges - and they are entitled to one which is accessible, free of obsolete law, with impartial and competent judges.

If one went into hospital for an operation would one expect the surgeon to operate with instruments more than 200 years old? What would be the result? So, should the law be any different? Especially, the criminal law? Should people be tried for crimes that are up to 700 years old? ${ }^{1}$ Crimes where the language is, sometimes, not in English but in Latin or Law French? Where there is, sometimes, a failure to specify the punishment? Where the wording of the relevant Act is tortuous and obscure? If a surgeon were to wield an ancient trepanning device to deal with a head wound, would the patient not have cause to complain? Why, then, does so much antiquated criminal legislation remain on our books? There is no need for this and it works injustice - from the outset - to persons who might be tried for such offences. Crimes should be intelligible to the accused as well as to their lawyers and judges. They should not require detailed research in the history books. We live in the Space age not the age of the Plantagenets. Thus, the law needs to move on. In the case of $R v$ Rusbridger (2003) ${ }^{2}$ the House of Lords made it clear that they did not support the retention of obsolete legislation. This has also been the common opinion of jurists for - at least - 200 years. Thus, Eden, in his Principles of Penal Law (1771) declared:

\footnotetext{
${ }^{1}$ The oldest crime still extant would seem to be that under the Statute of Westminster the First, 1275 , ch 5 (freedom of election), see Appendix A.

${ }^{2}$ In $R$ (Rushbridger) $v A-G$ [2004]1 AC 357 at pp 377-8 per Lord Walker 'it is most undesirable that obsolete statutes should remain unrepealed. Quaint language and interesting historical associations are no justification for preserving obsolete statutes in a mummified state.' Other judges in the case stated much the same.
} 
Obsolete and useless statutes should be repealed; for they debilitate the authority of such as still exist and are necessary. Neglect on this point is well compared by Lord Bacon to the cruelty of Mezentius who left the living to perish in the arms of the dead. ${ }^{3}$

A number of published articles ${ }^{4}$ have focused on antiquated criminal legislation - and common law crimes which (I have argued) are obsolete and should be repealed or abolished.

- This article summarizes crimes - and criminal procedure - still extant in legislation for the period 12671815 (including some Acts not previously analysed). It argues that all these should be repealed, with a few exceptions which need to be modernised;

- If this is done, the criminal law - at least in terms of legislation - will have progressed up to 1815. Nothing to rejoice over. However, at least, then people can only be tried for crimes that are 200 years old. And, if that is not bureaucratic - and judicial - progress, what is?

In reviewing these final pieces of legislation, it should be noted that they are scarcely touched on in the standard legal texts - both past ${ }^{5}$ and present. ${ }^{6}$ Further, generally, there is little caselaw. However, simply removing obsolete criminal legislation is insufficient in order to substantially improve the lamentable position in respect of English criminal law.

- At present, there are, at least, 155 Acts on criminal law, 104 Acts on criminal procedure and 27 Acts on criminal justice and the police (286 Acts in total);

- True, there is duplication in that some of the Acts on criminal law also contain matters of criminal procedure etc. That said, one can comfortably say that there are - in total - at least 220 distinct Acts on criminal law, criminal procedure and criminal justice presently in existence;

- There is also a huge volume of commencement SI, amendment Acts etc. emanating from these Acts;

- The above is continuing to grow, almost exponentially.

The result of all this comprises a huge administrative burden - on draftsmen, on the civil service, on bodies handling the criminal law, judges, lawyers etc. The same also constitutes a major financial burden on the taxpayer as well as taking up unnecessary court time. Clearly, something should be done. This article sets out a means of reducing this massive volume of legislation - much of which comprises amendments, cross-references, citations - to about 10 Acts. That is, a 22 times reduction.

\footnotetext{
${ }^{3}$ W Eden, Principles of Penal Law (1771, 2nd ed. London. Printed for B White), p 19. See also The Works of Francis Bacon (CUP, ed J Spedding et al, 1872, digitally printed 2011), vol 6, p 65 'There is a further inconvenience, of penal laws obsolete and out of use; for that it brings a gangrene, neglect, and habit of disobedience upon other wholesome laws that are fit to be continued in practice and execution; so that our laws endure the torment of Mezentius: the living die in the arms of the dead.'

${ }^{4}$ (a) Abolishing the Crime of Treason (2007) 81 Australian Law Journal 94-134; (b) High Treason: Killing the Sovereign or Her Judges (2009) 20 King's Law Journal 457-88; (c) High Treason: Violating the Sovereign's Wife (2009) Legal Studies, vol 29(2) 264-80; (d) Abolishing the Crime of Treason Felony (2007) 81 Australian Law Journal 812-38; (e) Abolishing High Crimes and Misdemeanours etc (2011) 85 Australian Law Journal 810-79; (f) Abolishing some Obsolete Common Law Crimes (2009) 20 King's Law Journal 89-114; (g) Abolishing Obsolete Legislation on Crimes \& Criminal Procedure (2010) Legal Studies, vol 30, no 3.

${ }^{5}$ The main historical texts on criminal law, after the date of the earliest legislation analysed are: (a) W Hawkins, A Treatise on Pleas of the Crown (E \& R Nutt \& R Gosling, Savoy, ${ }^{\text {st }}$ ed, 1716, last ed, $8^{\text {th }}$ ed, 1824); (b) M Hale, The History of the Pleas of the Crown (London, E \& R Nutt \& R Gosling, 1736, rep Law Book Exchange, 2004); (c) EH East, Treatise of the Pleas of the Crown (A Strahan, London, 1803); (d) W Archbold, Magistrates' Courts Criminal Practice (Sweet \& Maxwell, London, 2013); (e) JF Stephen, History of the Criminal Law of England (Macmillan, 1883); (f) J Chitty, Practical Treatise on the Criminal Law (S Brooke, London, $2^{\text {nd }}$ ed, 1826); (g) CS Kenny, Outlines of Criminal Law (1 $1^{\text {st }}$ ed, 1902, last ed 1966); (h) WO Russell, A Treatise on Crimes and Misdemeanours (1st ed 1819, last ed 1964); (i) SF Harris \& FP Tomlinson, Principles of Criminal Law (London, Stevens \& Haynes, 2nd ed, 1881; 8th ed, 1950).

${ }^{6}$ See, for example: (a) C McAlhone \& R Huxley-Binns, Criminal Law.The Fundamentals (2 $2^{\text {nd }}$ ed, 2010); (b) MJ Allen, Textbook on Criminal Law (1 $1^{\text {th }}$ ed, 2011); (c) A Ashworth, Principles of Criminal Law (6 $6^{\text {th }}$ ed, 2009); (d) Blackstone, Criminal Practice (23 ${ }^{\text {rd }}$ ed, 2013); (e) R Card, Criminal Law (20 ${ }^{\text {th }}$ ed, 2012); (f) CMV Clarkson \& HM Keating, Criminal Law, Text and Materials (7 $7^{\text {th }}$ ed 2010); (g) C Elliott \& F Quinn, Criminal Law (8 ${ }^{\text {th }}$ ed, 2010); (h) R Heaton, Criminal Law (2 ${ }^{\text {nd }}$ ed, 2006); (i) J Herring, Criminal Law (6 $6^{\text {th }}$ ed 2009); (j) M Jefferson, Criminal Law ( ${ }^{\text {th }}$ ed, 2009); (k) Lacey, Wells \& Quick, Reconstructing Criminal Law. Text and Materials (4 ${ }^{\text {th }}$ ed, 2010); (1) J Loveless, Complete Criminal Law. Text. Cases and Materials ( ${ }^{\text {rd }}$ ed, 2012); (m) N Padfield, Criminal Law ( $7^{\text {th }}$ ed, 2010); (n) A Reed \& B Fitzpatrick, Criminal Law (4 $4^{\text {th }}$ ed, 2009); (o) AP Simester, Simester \& Sullivan's Criminal Law: Theory and Doctrine (4 $4^{\text {th }}$ ed, 2010); (p) D Ormerod, Smith \& Hogan's Criminal Law (13 ${ }^{\text {th }}$ ed, 2011); (q) DJ Baker, Glanville Williams Textbook of Criminal Law (3 $3^{\text {rd }}$ ed, 2012); (r) Archbold, Criminal Pleading, Evidence and Practice (Sweet \& Maxwell. London, 2013); (s) Stone's Justices Manual. (Butterworths, 2013). It may be noted that the majority of these texts do not deal with the Acts mentioned in this article and, to the extent they do, it is usually only by way of a cross-reference.
} 


\section{Statutory Crimes: $1275-1815$}

Legislation relating to crimes - and criminal process - still extant for the period 1275-1815, comprises the following:

- $\quad$ Statute of Westminster 1275

- Bearing of Armour 1313

- Law Presentment 1351

- Treason Act 1351

- Liberty of Subject 1354

- Justices of the Peace Act 1361

- None to Answer without Due Process 1368

- Treason Act 1495

- Simony Act 1588

- Simony Act 1688

- $\quad$ Treason Act 1695

- Treason Act 1702

- Constables Protection Act 1750

- Offences at Sea Act 1799

- Criminal Jurisdiction Act 1802

- Writ of Subpoena Act 1805

- Witnesses Act 1806

- Treason Act 1814
1 section
1 section
1 section
1 section $^{7}$
1 section
1 section $^{8}$
1 section
2 sections
7 sections
2 sections
2 sections
1 section
1 section
1 section
1 section
2 sections
1 section
1 section

Those Acts (and crimes) which (it is asserted) should be abolished outright are in italics. They have been considered in previous articles. ${ }^{9}$ Thus, this article will analyse the following:

- Constables Protection Act 1750

- Writ of Subpoena Act 1805

- Universities Act 1825

It is asserted that the Acts of 1750 and 1805 should be modernised and the Universities Act 1825 repealed. If this were done - in respect of all legislation dealing with crimes and criminal process still extant in the period 12751815 - this would leave only the Habeas Corpus Acts ${ }^{10}$ which need to be considered in a separate analysis. So too, the Offences at Sea Act 1799 and the Criminal Jurisdiction Act 1802. ${ }^{11}$ Previous articles have also considered: (a) three obsolete common law crimes; ${ }^{12}$ and (b) a number of other pieces of legislation post-1815 dealing with crimes and criminal process. It is asserted that (a) be abolished and (b) repealed. ${ }^{13}$

\footnotetext{
${ }^{7}$ It is asserted only the offence of 'adhering' to the enemy should be preserved. This should become a new offence of treachery (one which is not linked to allegiance; one which is also based on the Treachery Act 1940). See n 4 (a)-(c).

${ }^{8}$ It appears that some lawyers allege part of this Act is not obsolete (this comprises wording which empowers JP's to bind over for good behaviour). See Appendix A. However, even if so, this would be resolved by amending the Justices of the Peace Act 1987, s 1 (7).

${ }^{9}$ See fn 4.

${ }^{10}$ Habeas Corpus Acts 1679, 1781, 1803, 1804, 1816 \& 1862.

${ }^{11}$ These are not complex. The Act of 1799 (which only comprises one sentence), essentially, provides that crimes under English law apply to the high seas. And the Act of 1802 (only a few lines are extant) provides that offences committed by public service employees abroad may be prosecuted in England and the offenders punished as if the offences had been committed in England.

${ }^{12}$ See Appendix A.

${ }^{13}$ Ibid.
} 


\section{Constables Protection Act 1750}

\section{(a) Introduction}

Today, the police have the ability in many instances to act without a warrant - including when making an arrest. ${ }^{14}$ Further, today, the police are a professional body and have much greater discretion - and power - than the constables of $1750 .{ }^{15}$ Back in 1750 - at the time of the Act - the constable was an amateur - often of dubious ability - ${ }^{16}$ the ministerial agent of the justice of the peace ('JP') who executed his warrants. He did not generally go out of his precinct. ${ }^{17}$ And JP's had a more limited jurisdiction, geographically, than in modern times. ${ }^{18}$

- This Act of 1750, therefore, pre-dates modern legislation which permits constables to act without a warrant. Its purpose was that - if a JP issued a warrant without jurisdiction - a constable (or other person) who acted in obedience to it, was protected from a civil action (but not a criminal prosecution) subsequently brought against him. ${ }^{19}$ Also, no action could be brought until a copy of the warrant had been demanded;

- As will be seen, it is asserted the Act of 1750 should be formulated in modern terms. Thus, in general, any person subject to a warrant should be entitled to a copy of it within 6 days of demand. Also, a constable (or person) acting in obedience to a warrant should be protected from any civil (or criminal) prosecution if he acts without malice or negligence.

\section{(b) Demand of Warrant}

The preamble to the Act ${ }^{20}$ states that it is: An Act for the rendering Justices of the Peace more safe in the execution of their office: and for indemnifying constables and others acting in obedience to their warrants. ${ }^{21}$ The only section of this Act still extant - section 6 - bears the headnote: 'Action not to be brought against any constable acting in obedience to justices warrant, till demand made of the sight and copy of the warrant, and [refund] thereof, etc.' It provides:

...no action shall be brought against any constable, headborough, or other officer, ${ }^{22}$ or against any person or persons acting by his order and in his aid, for any thing done in obedience to any warrant under the hand or seal of any [JP],,$^{23}$

\footnotetext{
${ }^{14}$ See Baker, n 6, p 313. See also Criminal Evidence Act 1984, s 24 (arrest without warrant). Cf. Magistrates Courts Act 1980, s 1 (1) 'Upon an information being laid before a [JP] for an area to which this section applies that any person has, or is suspected of having committed an offence, the [JP] may...(b) issue a warrant to arrest that person and bring him before a magistrates' court for the area or such magistrates'court as is provided in subsection (5) below.'

${ }^{15}$ A Gentleman of the Middle Temple, Readings upon the Statute Law (London, printed for the Author, 1723), vol 2, p 108, 'The constable is the proper officer to a justice of peace, and bound to execute his warrants.' See also Hawkins (1824), n 5, p 98. For the history of the constable, see Halsbury's Laws of England (4th ed), vol 36(1), para 101 et seq.

${ }^{16}$ Stephen, n 5, vol 1, p 196 'Nothing could exceed the inefficiency of the constables and watchmen. Of the constables, Dalton (in the reign of James I) [this is a reference to M Dalton, The Countrey Justice. London. For the Society of Stationers. 1619] observes that they 'are often absent from their houses, being for the most part husbandmen, and so most of the day in the fields.' The charge of Dogberry shows probably with no great caricature what sort of watchmen Shakespeare was familiar with.'

${ }^{17}$ A Gentleman, n 15, pp 110-1.

${ }^{18}$ Today, warrants of arrest, commitment, detention, distress or search issued by a JP of the peace may be executed anywhere in England and Wales by any constable acting withn his police area. See Halsbury, n 15, vol 36(1), para 478.

${ }^{19}$ Smith \& Hogan, n 6, p 683 summarised the Act as follows: 'Where a warrant is issued but the justice lacks jurisdiction to issue the warrant, the constable who arrests under the warrant is statutorily protected from any 'action' if he acts in obedience to it. As the term 'action' is inappropriate to a criminal proceeding, a constable could not rely on the Act as a defence to a criminal prosecution, but he would probably have a good defence on the ground of a lack of mens rea.'

${ }^{20} 24$ Geo 2 c 44. See also Halsbury, Statutes of England (4th ed), vol 35 and Halsbury Laws, $n$ 15. For a case on the equivalent section in the law of Northern Ireland see McGrath (AP) v Chief Constable of the Royal Ulster Constabulary and Another (NI) [2001] UKHL 39 (re Constabulary (Ireland) Act 1836, s 50 (6 \& 7 Will 4, c 13).

${ }^{21}$ The general observation of Eden on the unsatisfactory nature of preambles may be noted, n 3, p 313 'the effectual promulgation of the laws is much retarded by the manner in which they are formed... those tedious preambles, which seem to have been derived from the ancient method of passing laws by petition, are still retained, though frequently ill-connected with the subsequent parts of the law, to which they are prefixed.'

${ }^{22}$ This will include a jailer, see Butt v Newman (1819) Gow 97 (171 ER 850) (action for false imprisonment). See also Harper v Carr (1797) (101 ER 970, 1070) (churchwarden taking a distress for a poor rate under a warrant is within the Act). Also, Fletcher v Wilkins(1805) 6 East 283 (102 ER 1295)(parish officer).
} 
until demand hath been made or left at the usual place of his abode by the party or parties intending to bring such action, or by his, her, or their attorney or agent, in writing signed by the party demanding the same, of the perusal and copy of such warrant, ${ }^{24}$ and the same hath been refused or neglected for the space of [6] days after such demand ${ }^{25}$ (spelling modernized and wording divided for ease of reading).

The reference to 'headborough' is obsolete. ${ }^{26}$ Thus, the gravamen is that no action (this would not include a criminal prosecution) can be brought against a constable or other officer (or person acting under his orders) obeying a JP's warrant unless:

- $\quad$ a signed written demand is made (or left) by the person intending to bring the action (the plaintiff); ${ }^{27}$

- $\quad$ it is made (or left) at the usual place of abode of the constable;

- $\quad$ it demands 'the perusal and copy of such warrant';

- $\quad$ it has been refused (or neglected) for 6 days after it was made (or left).

This obligation on a potential litigant who seeks to bring an action against a constable needs to be considered with reference to the situation prevailing c. 1750.

- On the basis the constable was a sworn officer of the court, pre-1750, he did not have to show a copy of his warrant. ${ }^{28}$ This reflected not only the balance of power prevailing in those times in favour of the court and against a potential offender (or innocent party). It also reflected the rudimentary means of communications of those days. It would take time for the constable (walking or on horseback) to get a warrant from a JP; ${ }^{29}$

- Today, with modern technology and the desire that persons be informed of their legal rights, it is only proper that a person subject to a warrant should be entitled to a copy of it - in any case - on demand to the relevant court and this should be provided for;

- The Magistrates' Courts Act 1952, s 102(4) ${ }^{30}$ provided that a warrant to arrest a person charged with an offence could be executed by a person notwithstanding he was not in possession of it at the time. However, on the demand of the person arrested, the warrant should be shown to him as soon as practicable. ${ }^{31}$ Further, De Costa (1978) provided that an arrest under a warrant for a civil matter was unlawful if the arresting officer did not have the warrant in his possession; ${ }^{32}$

\footnotetext{
${ }^{23}$ Charleton v Alway (1840) 11 Ad \& El 993 (113 ER 691) (distress was levied by a constable for non-payment of tax. It was held he was not bound to join as co-defendants certain commissioners who issued the warrant since they were not JP's as such (although they were also acting as JP's for the division).

${ }^{24}$ A copy of the warrant is sufficient, the original is not necessary. Atkins $v$ Kirby (1840) 11 Ad \& El 777 (113 ER 609).

${ }^{25}$ Jones v Vaughan (1804) 5 East 445 (102 ER 1141) established that a constable was entitled to the protection of s 6 on proof of demand even when the warrant was not then supplied within the 6 day period, when the action was only commenced after compliance. See also Halsbury Laws, n 15, vol 36(1), para 523.

26. As Halsbury Statutes, n 20, vol 33(2), preliminary note to the Act, notes, the earliest form of police organization seemed to have been a local association of persons who - as the king's subjects - became sureties for one another's keeping the peace. These associations elected principal men called headboroughs, borsholders or tithingmen who were responsible for maintaining order in the association. DM Walker, The Oxford Companion to Law (Oxford, 1980) (definition of headborough). 'The chief of the 10 men who comprised a frankpledge (qv), elected by the court leet with the responsibility for the keeping of order in the area for which he was elected. They were gradually replaced by petty and parish constables.' See also Halsbury Laws, n 15, vol 36(1), para 101.

${ }^{27}$ It can also be brought by his agent or lawyer.

${ }^{28}$ See A Gentleman, n 15, p 109 'As the constable is a sworn officer, he need not show his warrant, and it is said, he may justify detaining an offender for a day, without a warrant.' Hawkins (1824 ed), n 5 vol 2, p 135 'a bailiff, or a constable, if they be sworn, and commonly known to be officers, and act within their own precincts, need not show their warrant to the party, notwithstanding that he demand the sight of it; but that these and all other persons whatsoever making an arrest, ought to acquaint the party with the substance of their warrants, and that all private persons to whom such warrants shall be directed and even officers, if they be not sworn and commonly known, and even these, if they act out of their own precincts, must show their warrants if demanded. And therefore it is enacted by 27 Geo 2 c 20 [1754, rep] that in all cases where any [JP] is required or empowered by any statute to issue a warrant of distress for the levying any penalty inflicted, or sum of money thereby directed to be paid, 'the officer executing such warrant, if required, shall show the same to the person whose goods and chattels are distrained, and shall suffer a copy thereof to be taken.'

${ }^{29}$ In those times there probably was also a tendency of JP's and constables to delay - or not wish to provide - warrants when any want of jurisdiction was alleged. Further, it should be remembered that, prior to 1829 and the beginnings of a modern police force, constables were often old and feeble of dubious competence, see $\mathrm{n} 16$.

${ }^{30}$ This Act was repealed by the Magistrates' Courts Act 1980.

${ }^{31}$ A constable was not required to inform a man when he was arrested whether the arrest was by virtue of a warrant or otherwise. $R v$ Kulynycz [1971] 1 QB 367.

${ }_{32}$ De Costa Small v Kirkpatrick (1978) 68 Cr App R 186, [1979] Crim LR 41 (warrant was at the police station, half a mile away). Cf. $R v$ Purdy [1975] QB 288 (warrant need not be actually on the person of the constable providing that it is in his possession in the sense of being under his control and available to be produced as part and parcel of the arrest. Warrant was in a police van, 50-60 yards away. Held this was sufficient possession). Galliard v Laxton (1862) 2 B \& S 363 (121 ER 1109)(warrant in respect of a bastardy order (a civil process) in possession of superior officer at the police station. Not called on to show it). Codd v Cabe (1876) 1 Ex D 352 (where warrant issued to
} 
- $\quad$ Further, it should be noted that the courts undermined the need for demand of a warrant as required by the Act of 1750. Thus, in Bell v Oakley $(1914)^{33}$ the defendants, to levy a poor's rate under a warrant of distress granted by two JP's, broke and entered the house and broke the windows. It was held they could be sued in trespass without a previous dermand of the perusal and copy of the warrant according to the Act. ${ }^{34}$

Today, in modern society, the onus should be on the State (the courts) to provide proof of the warrant and not the party subject to the warrant (who may be innocent of any offence).

- Thus, it is asserted that modern legislation should provide that: (a) a person subject to any warrant is entitled to see it; (b) a person subject to any warrant is entitled to a copy within 6 days of a written request. This should apply whether - or not - a party subsequently brings any action (civil or criminal) against a constable on the basis of lack of jurisdiction. Thus, the requirement of a warrant in the 1750 Act should now be 'severed' from any possible subsequent action against the constable. It should apply generally;

- The effect of this would clear up much uncertain law - especially - as to when a constable must have a warrant in his possession, as well as what 'possession' means. ${ }^{35}$ Today, it seems only appropriate (and reasonable) that a person be informed whether any action against them is by virtue a warrant (why on earth not?). Also, to see it on demand. The latter would clear up many of the problems relating to the warrant being issued with a defect of jurisdiction (see below) as well as save court time - and expense having to deal with such cases.

\section{(c) Defect in JP's Jurisdiction}

\section{Section 6 also provides:}

and in case after such demand and compliance therewith, by showing the said warrant to and permitting a copy to be taken thereof by the party demanding the same, any action ${ }^{36}$ shall be brought against such constable, headborough, or other officer, or against such person or persons acting in his aid for any such cause as aforesaid, ${ }^{37}$ without making the justice or justices who signed or sealed the said warrant defendant or defendants, that on producing and proving such warrant at the trial of such action the jury shall give their verdict for the defendant or defendants, notwithstanding any defect of jurisdiction in such justice or justices;

and if such action be brought jointly against such justice or justices and also against such constable, headborough, or other officer or person or persons acting in his or their aid as aforesaid, then, on proof of such warrant, the jury shall find for such constable, headborough, or other officer, and for such person and persons so acting as aforesaid, notwithstanding such defect of jurisdiction as aforesaid; (wording divided and spelling modernized for ease of reading) ${ }^{38}$

In summary, where (a) has been complied with:

- $\quad$ but the JP (or JP's) who issued the warrant is not made a defendant - the jury shall give their verdict for the constable (or other person) notwithstanding any defect of jurisdiction in such JP; ${ }^{39}$

apprehend a person for an offence less than felony, constable who executes it must have the warrant in his possession at the time of arrest. Here, arrest held not justified). Also, Horsfield v Brown [1932] 1 KB 385 (Constable did not have the warrant (in respect of unpaid maintenance in his possession at the time he effected the arrest. It was at the police station). At p 365 per Macnaghten J 'by the common law the constable could not lawfully make the arrest unless he had the warrant with him at the time.' See also Cotton $v$ Kadwell (1833) 2 Nev \& M (KB) 399 (unnecessary to demand perusal and copy of a warrant in a case where there is no remedy against the JP's).

${ }^{33}$ (1814) 2 M \& S 259 (105 ER 378). This case is not mentioned by Halsbury Laws, n 15, vol 36(1), para 523 though it notes Atkins $v$ Kirby (1840) 11 Ad \& El 777 (113 ER 609)(substantial although not literal compliance in the case of the provision of a copy of a warrant).

${ }^{34}$ See also Palmer v Crone [1927]1 KB 804 (no demand for a copy of the warrant was made and the constable was protected from a claim for damages for seizing goods under an illegal distress warrant).

${ }^{35}$ See $\mathrm{n} 32$.

${ }^{36}$ Fletcher $v$ Wilkins (1805) 6 East 283 (102 ER 1295). Replevin is not an action within the Act which protects acting under a JP's warrant.

${ }^{37}$ Jones $v$ Chapman (1845) 10 JP 153. See also Halsbury Laws, n 15, vol 36(1), para 523.

${ }^{38}$ The final part of s 6 provides: "if the verdict shall be given against the justice or justices, that in such case the plaintiff or plaintiffs shall recover his, her, or their costs against him or them, to be taxed in such manner by the proper officer as to include such costs as such plaintiff or plaintiffs are liable to pay to such defendant or defendants for whom such verdict shall be found as aforesaid. (spelling modernized).

${ }^{39}$ Harris, n 5, p 309 (1881 ed) 'a warrant drawn up according to the statutory form will (even though the magistrate who issued it has exceeded his jurisdiction), indemnify the officer who executes the same ministerially.' 
- if the action is brought jointly against the JP and the constable, on proof of the warrant, the jury shall find for the constable notwithstanding such defect of jurisdiction;

The purport of s 6 was summarized in Hoye v Bush (1840) per Coltman J:

The object of [s 6] was to meet a difficulty which occurred frequently in practice, where the officer acted under the warrant of a magistrate who had no jurisdiction. ${ }^{40}$

There was a public policy reason behind this, as Eldon CJ noted in Price v Messenger (1800):

The public interest requires that officers who really act in obedience to the warrant of a magistrate should be protected. In such cases, therefore, the law has provided that the remedy of the party grieved shall be confined to the magistrate, as well where he has granted a warrant without having jurisdiction, as where the warrant which he has granted is improper. ${ }^{41}$

Halsbury summarises the position as follows:

In executing a warrant a constable must act strictly according to its terms, otherwise he will be liable to a claim against him. If he acts in obedience to a warrant issued by a [JP], he has a good defence in any proceedings for tort ${ }^{42}$ which may be brought against him, notwithstanding some defect in the justice's jurisdiction, provided that the constable complies within six days with any written demand for a sight of and an opportunity to copy the warrant. ${ }^{43}$

Price $v$ Messenger (1800) ${ }^{44}$ clarified the Act covered the situation where a JP granted a warrant improperly as well as where he acted without jurisdiction. However, it did not cover constables acting under warrants issued by justices of the King's Bench. ${ }^{45}$ Further, it only protected constables (or other persons acting under the warrant) where they acted in obedience to the warrant - not when the acted unlawfully ${ }^{46}$ As to the wrongful execution of a warrant by a JP, Clerk and Lindsell cite various instances of the wrongful execution of a warrant, ${ }^{47}$ viz:

- Misdirected Warrant. The person may not be the one to whom the warrant was directed. For example, where a constable arrests A with a warrant directed to B. ${ }^{48}$ Today, this will not matter providing the constable acts within his police area; ${ }^{49}$

- Wrong Goods. A constable cannot be justified if he takes C's goods under a distress against B (ie. goods not referred to in the warrant are taken $)^{50}$ unless it is reasonably believed they are also stolen. The history of this (and the changing development) was analysed by Lord Denning in Chic Fashions

\footnotetext{
${ }^{40}$ [1835-42] All ER Rep 286. Maule J at p 290 'The object of that section is to protect the officer, notwithstanding any defect of jurisdiction in the justice [JP], on the production of proof of the warrant.' Jones $v$ Vaughan (1804) 5 East 445 (102 ER 1141) at p 448 per Lawrence J 'The object of the clause in question was the protection of those officers who are charged with the execution of magistrates' warrants, who before that time were subject to indictment if they did not execute the warrants directed to them, or to vexatious actions if they did. For this purpose the legislature proposed to substitute the magistrate by whom the warrant was granted, and who was supposed to be cognizant of the legality of it, in lieu of the officer who was merely the instrument to execute it, and who was probably ignorant of the grounds on which it was issued.' See also Clerk \& Lindsell on Torts (20th ed, 2010), p 912, para 5-121.

${ }^{41} 2$ B \& P 158 (126 ER 1213) at p 161. See also Kay v Grover (1831) 7 Bing 312 (131 ER 120) per Tindal CJ at p 314 'Before the passing of that statute the consequences of a want of jurisdiction in the magistrate who issued the warrant often fell on the officer, who was bound to obey it.'

${ }^{42}$ Lyons $v$ Golding (1829) 3 C \& P 586 (172 ER 557). A party cannot maintain trover against a constable for a wrongful taking of goods under a JP's warrant without joining the JP as defendant. See also F Buller, Law of Trials at Nisi Prius (7th ed, 1817), p 24, note 'The ....Act extends only to actions in tort: And therefore where an action for money had and received was brought against an officer who had levied money on a conviction by a justice of the peace, the conviction having been quashed, it was holden that a demand of a copy of the warrant was not necessary. See also Halsbury, n 15, vol 36(1), para 523 which refers to Milward v Caffin (1799) 2 Wm Bl 1350 (96 ER 779) (replevin), Fletcher v Wilkins (1805) 6 East 283 (see n 36). Cf. Pearson v Roberts (1755) Willes 668 (125 ER 1376) and Harper v Carr (1797) 7 Term Rep 270 (101 ER 970, 1070).

${ }^{43}$ Halsbury, n 15, vol $36(1)$, para 523.

${ }^{44} 2$ B \& P 158 (126 ER 1213) (if the warrant be to seize stolen goods and the officer seized goods which turned out not to have been stolen, then still protected by the Act).

${ }^{45}$ Gladwell v Blake (1834) 1 Cr M \& R 636 (149 ER 1235).

${ }^{46}$ Horsfield v Brown [1932] 1 KB 385 at p 369 per Lord Macnaughten 'He had no right to execute the warrant at any time, or in any place or in any manner forbidden by law.' Also 'if the warrant be a lawful warrant, and he executes it in an unlawful way, then no action is maintainable against the magistrate, but an action is maintainable against the constable.'

${ }^{47}$ Clerk \& Lindsell, n 40, para 5-122. See also Thomas [1962] Crim LR 597.

${ }^{48}$ Hoye $v$ Bush [1835-42] All Er Rep 286 (JP issued a warrant for John Haye. The person arrested was, in fact, Richard Haye - the person intended to be named). See also, Kay v Grover (1831) 7 Bing 312 (131 ER 120) (warrant executed not against A but his landlord who had taken the goods in the warrant as distress for rent). See also Money v Leach (1765) 3 Burr 1742 (97 ER 1075), at p 1768.

${ }^{49}$ Magistrates' Courts Act 1980, s 125(2).

${ }^{50}$ As Halsbury notes, n 15, vol 36(1), para 482 'A constable has certain statutory powers to enter and search premises without a warrant. These powers apart, in the absence of consent he has only a right to search premises in pursuance of a search warrant issued by a justice of the peace.' See also Clerk \& Lindsell, n 40, para 5-122. Also, Police and Criminal Evidence Act 1984, s 19.
} 
(West Wales) Ltd $v$ Jones (1968). ${ }^{51}$ The conclusion was that, when a constable entered a house by virtue of a search warrant for stolen goods, he could seize not only goods he reasonably believed to be covered by the warrant but also other goods he believed (on reasonable grounds) to have been stolen and to be material evidence on a charge of stealing (or receiving) against the person in possession of them (or anyone associated with him); ${ }^{52}$

- Wrong Time. A constable cannot be justified if he executes the warrant at the wrong time. ${ }^{53}$ As a rule, warrants may be executed at any time of the day (however, in relation to search warrants, it is the usual and proper course to direct that the search should only take place in the day time) ${ }^{54}$

- $\quad$ Failure to Give Due Notice. A constable cannot be justified if he fails to give due notice of the grounds on which he claims to apprehend; ${ }^{55}$

- No Warrant with Him. A constable may not have the warrant with him at the time of the alleged wrongful act. He who would seek to execute a warrant ought to be in a position to produce it, if demanded; ${ }^{56}$

- $\quad$ Breaking Outer Door. A constable may execute the warrant improperly by breaking open an outer door. If so, not only breaking the door - but the subsequent arrest - will be an unlawful act; ${ }^{57}$

- $\quad$ Assault. A constable may - at the time of the arrest or seizure - be guilty of an assault. Or subsequent thereto, he may improperly confine his prisoner or otherwise act in an unauthorized manner (however, this will probably not make him a trespasser $a b$ initio);

- Excessive Distraint. If the constable exercises excessive distraint; ${ }^{58}$

- $\quad$ Searching Persons. A constable may - executing a warrant to search premises - search persons found thereon. This is unlawful unless the warrant expressly includes the search of persons; ${ }^{59}$

- $\quad$ Police and Criminal Evidence Act 1984. Section 16 enacts detailed rules for the execution of search warrants; ${ }^{60}$

- Wrong Constable Executes Warrant; ${ }^{61}$ Today, this is unlikely. Magistrates may direct warrants for the apprehension of persons charged with offences - whether on indictment or punishable by summary

${ }^{51}$ [1968] 2 QB 299. The original position as to stolen goods was established in Entick v Carrington [1558-1774] All ER Rep 41and (1765) 2 Wils 275. In November 1762, the Earl of Halifax (Secretary of State) issued a warrant to search for 'John Entick, the autor, or one concerned in writing the Monitor'. The messengers seized him and his papers. On trespass the jurors found a special verdict. Lord Camden delivered the judgment of the court, that a warrant to seize and carry away papers in the case of a seditious libel was illegal and void. His lordship noted that warrants to search for stolen goods had crept into the law by imperceptible practice; that it is the only case of its kind to be met with; and that the law procedes in it with great caution. For 1st, there must be a full charge, upon oath, of a theft committed. 2ndly, the owner must swear that the goods are lodged in such a place. 3rdly, he must attend at the execution of the warrant to show them to the officer, who must see that they answer the description. And lastly, that the owner must abide the event at his peril; for if the goods are not found, he is a trespasser; and the officer being an innocent person, will be always a ready and convenient witness against him. 11 ST 321 . See also Hawkins (1824), n 5, vol 2, pp 133-4. This case is referred to in Chic Fashions (West Wales) Ltd v Jones [968] 2 QB 299, at p 308 per Lord Denning.

${ }^{52}$ See especially judgment of Lord Denning, pp 309-14. Halsbury, n 15, vol 36(1), para 482 'this appears to be the application to the case of stolen goods of a wider proposition, the underlying principle of which is that where a constable has reasonable grounds for believing that the person concerned has committed or is implicated in a crime, the constable may seize an article held by that person which the constable reasonably believes to be the fruit of a crime, or an instrument used in a crime or otherwise material evidence of it.' The principle may also extend to the case where the refusal of the person to hand over the article is quite unreasonable. See Ghani v Jones [1970] 1 QB 693, 709.

${ }^{53}$ Clerk \& Lindsell, n 40, para 5-122 note - as regards place - there is no longer any difficulty as a warrant issued by a JP may be executed anywhere in England and Wales. See Magistrates' Courts Act 1980, s 125(2). Cf. Milton v Green (1804) 5 East 233 (102 ER 1059). The warrant was directed to the constable of Kent but, in fact, it was not executed in Kent but in the jurisdiction of the Cinque Ports. Held, not protected by s 6 . It may be noted this Cinque Ports jurisdiction no longer exists. See also Halsbury, n 15, vol 36(1), para 102 'a member of a police force now has all the powers and privileges of a constable throughout England and Wales and the adjacent United Kingdom waters and not merely within his own area.' See also para 477.

54 Ibid.

${ }^{55}$ Clerk \& Lindsell, n 40, para 5-122 cite MacKelley's Case (1611) 9 Rep 65 at 68; $R$ v Howath (1828) 1 Moo CC 207 (168 ER 1243 )(arrest without warrant under 3 Geo 4 c 40 s 5 entitled 'Any person may arrest offenders' (rep)). See also Christie v Leachinsky [1947] AC 573.

${ }^{56}$ See $n 32$

${ }^{57}$ Clerk \& Lindsell, n 40, para 5-122.

${ }^{58}$ Sturch v Clarke (1832) 4 B \& Ad 113(110 ER 398) at p 114 per Parke J 'this is an action for seizing goods more than reasonably sufficient for the probable exigency of the distress warrant; an excess for which the justices could not possibly have been made joint defendants. In such a case the Act does not apply.' See also Cotton $v$ Kadwell (1833) 2 Nev \& M (KB) 399.

${ }^{59}$ Herman King $v R$ [1969] 1 AC 304 (decision of the privy council).

${ }^{60}$ See also Police and Criminal Evidence Act 1984, s 15(1) 'an entry or search of premises under a warrant is unlawful unless it complies with this subsection and s 16 below.' See also $R v$ Longman [1988] Crim LR 534 and $R v$ Central Criminal Court and British Railways Board ex $p$ AJD Holdings Ltd, Royle and Stanley Ltd (1992) [1992] Crim LR 669

${ }^{61}$ Freegard $v$ Barnes \& Barton (1852) 7 Exch 827 (155 ER 1185). The party to execute was the parish constable of Dauntsey, which the defendant was not. It may be noted that parish constables no longer exist. 
conviction - to any constable by name or by description of his office, or to any particular constable or to all other constables within their jurisdiction or generally to all constables within their jurisdiction. Any such warrant may be executed in any county (or place) in England or Wales - either by the person to whom the warrant was originally directed or by any constable of the county (or place) in which the arrest takes place. ${ }^{62}$

\section{(d) Is the Act of 1750 still Necessary?}

It seems clear this Act of 1750 should be modernized. In particular,

- Any person subject to a warrant in respect of a criminal - or civil - matter should be entitled to see it on request. There is no good reason, these days, why constables should not have warrants in their possession;

- Any person subject to a warrant in respect of a criminal - or civil - matter should be entitled to a copy of it within 6 days of request. The modern means of copying, means that obtaining a copy is a simple administrative matter, unlike in olden times. Doing this alone would remove much old caselaw in respect of the need to provide a warrant as well as many of the current grounds as to unlawful execution; ${ }^{63}$

- When a JP issues a warrant, his should be the primary responsibility if it is defective. The constable (or other person) is an innocent agent and he should not, in law, be held responsible. Thus, no action (or criminal prosecution) should be possible against him acting in obedience to a warrant save where he himself acts: (a) not bona fide; or (b) negligently. The latter would include the caselaw situations outlined in (c) above.

It may be noted that - in the case of JP's - pursuant to the Courts Act 2003, they have immunity from being sued for their actions except if they have acted outside their jurisdiction and not bona fide. ${ }^{64}$ If the Act of 1750 we so replaced, this would remove a lot of uncertainty and old law. ${ }^{65} \mathrm{New}$ legislation:

- should apply whether a criminal prosection or a civil action is brought (under the Act it only applies to the latter);

- should cover any action under the warrant (replevin and non-tort matters are not covered by the Act);

- should apply to any form of warrant - including a king's bench warrant.

In conclusion, the protection of the police when executing warrants is important. The law should clarify when they are liable to prosecution for their own acts.

\section{Writ of Subpoena 1805}

This Act ${ }^{66}$ bears the long title: An Act to amend two Acts of the Thirteenth and Forty-Fourth years of his present Majesty [George III (1760-1820)], ${ }^{67}$ for the more effectual execution of the criminal laws, and more easy apprehending and bringing to trial offenders escaping from one part of the United Kingdom to the other, and from one county to another. Section 3 is headed 'Services of sub-poena in any part of the United Kingdom valid as to appearance in any other part.' It provides:

And whereas it is fit to provide for the appearance of persons to answer in case where warrants are not usually issued, and to give evidence in criminal prosecutions in every part of the [UK]: Be it further enacted that the service of every writ of subpoena or other process upon any person in any one of the

\footnotetext{
${ }^{62}$ Clerk \& Lindsell, n 40, para 5-124.

${ }^{63}$ For example, if the recipient of the warrant could view it, there is a good chance there would not then be problems in respect of the wrong person, wrong goods, excessive distraint etc.

${ }^{64}$ Courts Act 2003, ss 31-3. See also Clerk \& Lindsell, n 40, para 17-128.

${ }^{65}$ In particular, it would: (a) obviate any distinction between JP's warrants and those of the King's Bench; (b) extend protection to any action (and not just torts under the 1750 Act); (c) extend protection to criminal prosecutions (and not just to civil actions); (d) remove a lot of caselaw in respect of the need to provide a copy of the warrant; (e) remove a lot of caselaw in respect of what the 'possession' of a warrant means.

${ }^{66} 45$ Geo 3 c 92.

${ }^{67}$ These Acts have been repealed.
} 
parts of the [UK], requiring the appearance of such person to answer or give evidence in any criminal prosecution in any other parts of the same, shall be as good and effectual in law as if the same had been served in that part of the [UK] where the person so served is required to appear;

Thus, the service of a subpoena (or other process) in any part of the UK is effective in any other part. The section then deals with default of appearance. It continues:

and in case such person so served shall not appear according to the exigence of such writ or process, it shall be lawful for the court out of which the same is issued, upon proof made of the service thereof to the satisfaction of the said court, to transmit a certificate of such default under the seal of the same court, or under the hand of one of the judges or justices of the same, to the [High Court] in England in case such service was had in England, or, in case such service was had in Scotland, to the Court of Justiciary of Scotland, or in case service was had in Ireland, to the [High Court of Justiciary of Northern Ireland]; and the said last mentioned courts respectively shall and may thereupon proceed against and punish the person so having made default in like manner as if they might have done if such person had neglected or refused to appear in obedience to a writ of subpoena or other process issued out of such last mentioned courts respectively.

There appears to be no caselaw on this section and its meaning seems clear. Since this section is still relevant in modern times, it is asserted that the wording should be modernized. ${ }^{68}$ Section 4 is headed: 'Expence of attendance on writs of subpoena to be tendered'. It states:

Provided always...that none of such last-mentioned courts shall in any case proceed against or punish any person for having made default by not appearing to give evidence in obedience to any writ of subpoena or other process for that purpose unless it shall be made to appear to such court that a reasonable and sufficient sum of money to defray the expenses of coming and attending to give evidence and of returning from giving such evidence had been tendered to such person at the time when such writ of sub-poena or other process was served upon such person.

This wording should also be modernized. ${ }^{69}$

In conclusion, this Act should be modernized in order to make it more intelligible. This would not seem onerous.

\section{Universities Act 1825}

This Act ${ }^{70}$ is entitled 'An Act for the better preservation of the peace and good order in the universities of England'. Its preamble is 'Whereas it is expedient to add to the means anciently provided for maintaining peace and good order in the universities of Oxford and Cambridge.' Section 1 is headed 'Chancellor or Vice Chancellor of Universities may appoint Constables' ${ }^{71}$ Thus:

it shall be lawful for the chancellor or vice chancellor of the said universities...to appoint such number of able men as he shall think fit to be constables in and for the said universities... who shall continue in office either during good behaviour or during pleasure, or for such period of time, either defined or dependent on future circumstances, as such chancellor or vice chancellor shall direct. ${ }^{72}$

Once appointed, the Act provides that a constable:

- has full power to act as a constable within the precincts of the relevant university and 4 miles of the same;

\footnotetext{
${ }^{68} \mathrm{Viz}$. something to effect that: '(a) A person may be served with a subpoena or other process in any part of the [UK], requiring him to appear to answer, or give evidence, in any criminal prosecution in any other part; (b) Default shall be punished in the same manner as if such person had neglected or refused to appear in the former part; (c) Proof of default shall be by means of a certificate issued under the seal of the court or under the hand of one of the judges or justices of the same to the: (i) High Court in England where service was had in England; (ii) Court of Justiciary of Scotland, where service was had in Scotland; or (iii) High Court of Justiciary of Northern Ireland where service was had in Northern Ireland.'

${ }^{69} \mathrm{Viz}$. 'Default shall not be punished unless the court is satisfied a reasonable sum of money to defray the cost of appearing (both coming and going) had been tendered to such person when served with the subpoena or other process.'

${ }^{70} 6$ Geo 4 c 97.

${ }^{71}$ Provision is also made for any pro vice (or deputy vice) chancellor to appoint constables. Universities Act 1825 , s 2.

${ }^{72}$ Universities Act 1825, s 1. See also Halsbury Laws, n 15, vol 36(1) para 134 and Russell, n 5, pp 658-60. See also Kenny, n 5, p 221

'Police officer'includes proctors' constables in the Universitiess of Oxford and Cambridge, appointed under 6 Geo IV, c 97.'
} 
- is subject to the 'like powers and authorities' of JP's 'within the limits of their respective jurisdictions as other constables are subject to';

- shall also enjoy 'all such powers and authorities, privileges, immunities, and advantages' as any constables have (or shall have) within his constablewick. However, he shall be liable for any act done by him in the execution of his office and be liable to be sued - or indicted - in the courts of common law.

There appears to be no caselaw in respect of this $\mathrm{Act}^{74}$ which pre-dates the beginnings of a modern police force in 1829. The Act was designed to supplement the powers of the university proctors to enforce discipline at Oxford and Cambridge by creating a private constabulary. ${ }^{75}$ However,

- In 2003, Oxford university terminated its private constabulary in order to avoid the complexity and costs of complying with new standards. Thus, Oxford 'Bulldogs' were abolished by the University Council in 2003 - being re-designated 'Proctor's Officers' without constabulary powers. This occured, in part, it seems, as a result of complaints by local traders that they should not be subject to a private constabulary, not being members of the university; ${ }^{76}$

- In the case of Cambridge university, there are extant c. 20-30 constables (the so-called Cambridge University Constablulary). However, they generally restrict their activity to internal university matters crimes and other serious incidents being dealt with by the professional police (the Cambridgeshire Constabulary).

Thus, in the case of Oxford university, this Act is obsolete. In the case of Cambridge university it is contended it is no longer required for the following reasons:

- Historical Reasons. There was no particular reason - other than a historical one - for Oxford and Cambridge to have such legislation. In modern times, other universities and institutes of education have campi - and student numbers as large - to whom the Act could (should) equally apply (eg. Durham university and various London universities). Yet, the lack of a private constabulary has not disadvantaged them;

- Geographical Ambits too Wide. The power of the constables under the Act is too wide today - in terms of physical ambits and applying other than to students. The Act covers not only the university per se but also up to 4 miles from the same. However, it is difficult to delinate - in terms of territory - what now comprises Cambridge university as such. Further, there is no need for the special constabulary to exercise power outside the Cambridge Colleges since the Cambridge Constabulary now operate elsewhere in the town;

- $\quad$ Powers of JP's. The reference to the 'like powers and authorities of [JP's] within the limits of their respective jurisdictions' is obsolete. This was when there was no professional police body and when constables invariably operated under the orders of JPs in respect of warrants. ${ }^{77}$ Also, when their office was ministerial and not also quasi-judicial, ${ }^{78}$

- $\quad$ Negligence. Where the Chancellor (or Vice-Chancellor) appoints a constable who then operates outside the 4 mile limit - or operates negligently - the Chancellor (or Vice) could be vicariously liable. Why take such a risk in modern times?;

- Police \& Criminal Evidence Act 1984. This Act, s 24 (4), provides that 'any person' may arrest without a warrant: (a) anyone who is in the act of committing an arrestable offence; (b) anyone whom he has reasonable grounds for suspecting to be committing such an offence. And (5) provides that - where an

\footnotetext{
${ }^{73}$ Ibid. This is 'notwithstanding such constable may be a member of the university, and notwithstanding any claim of cognizance or privilege whatsoever.'

${ }^{74}$ At least, Halsbury and the main legal websites appear to disclose none.

${ }^{75}$ It should be noted that, pre- 1825 , the universities of Oxford and Cambridge very much dominated the towns. This is not so today. Further, students generally were much more turbulent.

${ }^{76}$ See Wikipedia 'In 2002, a group of local traders in Oxford wrote to Ewan Harris, a local MP, requesting the removal of the police powers of the constables over citizens who were not members of the university.'

${ }^{77}$ Chitty, n 5, vol 2, p 98 'it is said, that a constable was at the common law a subordinate officer to the conservators of the peace; and consequently since the officer of such conservators hath been disused, and justices of the peace constituted in their stead, it hath always been holden, that the constable is the proper officer to a justice of peace, and bound to execute his warrants.'

${ }^{78} \mathrm{Ibid}, \mathrm{p} 98$ 'inasmuch as the office of constable is wholly ministerial and no way judicial.'
} 
arrestable offence has been committed - any person may arrest without a warrant: (a) anyone who is guilty of the offence; (b) anyone he has reasonable grounds for suspecting is guilty of it; ${ }^{79}$

- $\quad$ No Need for Constabultary Powers. Like Oxford, there is no need - in modern times - for Cambridge to retain an independent constabulary who are answerable only to the Chancellor (an honorary appointment) or the Vice Chancellor (who has many other things to attend to and cannot supervise them in person). If this Act were repealed, there would be nothing to prevent Cambridge - like Oxford simply re-branding their constabulary as assistants to the proctors;

- $\quad$ Need for Professionalism. Both Cambridge citizens (and students) should not be subject to arrest by amateurs. They are entitled to be subject to the same professional police force as their fellow citizens or otherwise to be governed by the general law such as the Police and Criminal Evidence Act 1984 (see above). As it is, the Cambridge University Constabulary - in practice - do not exercise their full constabulary powers, doubtless, as a result of this as well as concerns of their being subject to litigation if they have acted improperly or outside their jurisdiction.

In conclusion, this Act is no longer required in the case of Oxford University, where it is obsolete. Further, it is not necessary or appropriate in the case of Cambridge University. The general law should apply. ${ }^{80}$

\section{Consolidating Criminal, Criminal Procedure \& Justice Legislation}

Having analysed these obsolete pieces of legislation, consideration needs to be given to consolidating criminal, criminal procedure and criminal justice legislation in general in order to make it more intelligible and userfriendly. As noted in section 1, there are, presently, some 220 distinct Acts - a huge, amorphous, mass that has built up over the centuries. This should be drastically curtailed. If one analyses: (a) the criminal legislation cited in Halsbury's Statutes of England and Wales, volumes 12(1)-(5)); (b) the legal websites of the principal law publishers such as Butterworths and Sweet and Maxwell as well as the Statute Law Database and; (c) modern legal texts dedicated to criminal law, ${ }^{81}$ it seems clear that a good way to consolidate this legislation is as follows:

- Criminal Legislation. Initially, this could be consolidated into 4 Acts viz: (a) Offences v the Person (including attempts, conspiracy); (b) Sexual \& Decency Offences; (c) Offences v Property \& Financial Crimes; (d) Offences v Public Order (inc. crimes relating to weapons, explosives, drugs, alcohol, vehicles and sports). The text, Archbold on Criminal Pleading, Evidence and Practice, has more divisions. ${ }^{82}$ However, these are only with regard to model indictments and some (such as those dealing with customs and road traffic) are better reserved to specific Acts. These six Acts could, later be contracted to 4 . Such a mode of proceeding will also make it easier to add in common law offences which subsequently become statutory. See also Appendix C;

- Criminal Procedure Legislation. This could be consolidated into two Acts viz. (a) Criminal Procedure Part 1 (covering evidence and procedure); (b) Part 2 covering Proceeds, Terrorism \& Extradition - all of which have been consolidated fairly recently into modern Acts and the further consolidation of which would be straightforward and not be time consuming. See also Appendix D;

- Criminal Justice. This should be one Act. It will comprise the residue. At the moment this is spread over many Acts. It would further help if: (a) police; (b) prison; and (c) terrorism material were to be 'carved out' of the above and placed into separate Acts.

Thus, it is asserted that the current morass of legislation should be consolidated as follows:

\footnotetext{
${ }^{79}$ See also Smith \& Hogan, n 5, p 451. Section 24(3) provides that these sections apply to conspiring, attempting,inciting, aiding, abetting, counselling or procuring an arrestable offence and that these acts are also arrestable offences.

${ }^{80}$ If the Cambridge Constablulary are insufficient to deal with specfic incidents relating to the university, the chief of police of the police force maintained for a police area may appoint special constables for that area. See Halsbury's Laws, n 15, vol 36(1), para 109.

${ }^{81} \mathrm{See} \mathrm{n} 6$. As to the method of assembling the contents of Appendices C-E, Halsbury lists criminal, criminal procedure and criminal justice material in vols 12(1)-(5). However, since much of this has been subsequently amended, I have checked its status against the Statute Law Database (which is not fully up to date at times) and the Westlaw database (which is, probably, the most accurate of all). I have also reviewed the legislation cited in the indices in Archbold and other modern criminal law texts (see n 6). It should be noted that Appendices C-E comprise the most commonly cited criminal legisation. A number of crimes are also contained in more specific Acts (such as legislation on animals, on aviation etc) and (it is asserted that) it is better they remain there rather than being in a general Crime Act.

${ }^{82}$ The cover of Archbold 2013 (see n 6) splits offences into those relating to: (a) administration of justice; (b) aiding and abetting; (c) attempts; (d) counselling and procuring; (e) criminal damage etc; (f) revenue and customs; (g) drugs; (h) explosives; (i) financial crime; (j) forgery etc; (k) fraud; (l) homicide and ancillary; (m) offences against public morals; (n) offences against the person; (o) offensive weapons; (p) public nuisance; (q) public order; (r) road traffic; (s) sexual; (t) national security; (u) theft.
} 
- Crime Acts. Consolidate to 4 (about c.1211 sections in total); ${ }^{83}$

- Criminal Procedure Acts. Consolidate to two (about c 1471 sections in total); ${ }^{84}$

- Criminal Justice Act;

- Police Act;

- Prison Act;

- Terrorism Act.

The effect of consolidation would be to reduce some 220 Acts into 10 Acts. Consolidation would also eliminate, at least, 500 sections comprising citation sections, commencement sections, amendment sections, cross reference sections etc. It is also asserted that:

- Consolidating criminal justice legislation should be left to last, being easier that way;

- The ideal means to speedily progress consolidation would be for two Parliamentary draftsmen (or Law Commission personnel) to consolidate criminal legislation at the same time as well as a third consolidating criminal procedure legislation. Obviously, this should happen only after - or at the same time as - obsolete legislation is removed;

- There is a bewildering number of titles in respect of criminal, criminal procedure and criminal justice legislation (see Appendices C-E). These titles are often confusing or they mean little (eg. many 'criminal justice' Acts actually contain crimes and matters of criminal procedure as well). If titles of Acts were shortened this would save much administration and paper - as well as be made more intelligible to the general public and lawyers. Thus, it is asserted that 'Crime Acts' should contain offences, 'Criminal Procedure Acts' should contain material on criminal procedure and 'Criminal Justice Acts' the remainder.

\section{Conclusion}

In modern times, it is essential that our criminal law is clear and intelligible. Also, that it be consolidated. This article asserts that all legislation relating to criminal law and procedure prior to 1800 should be repealed save for a few provisions. These should be consolidated in one Act. These provisions will cover the following:

- Immunity of police constables for their acts; ${ }^{85}$

- Habeas corpus;

- Treachery ${ }^{86}$

- Extra-territorial jurisdiction; ${ }^{87}$ and

- Sub-poenas. ${ }^{88}$

These provisions would comprise 6-8 sections in all, ${ }^{89}$ replacing some 19 old Acts (or, rather, snippets of the same). This residue - as well as all the other principal pieces of criminal legislation, criminal procedure and justice legislation referred to in Appendices C-E - should then be consolidated into 10 Acts.

\footnotetext{
${ }^{83}$ It would be c 1043 sections if material on nuclear/chemical weapons ete were taken out.

${ }^{84}$ One of these Acts would consolidate Extradition and Proceeds material (c 800 sections) leaving Criminal Evidence and Procedure to cover c 671 sections.

${ }^{85}$ ie. material in the Constables Protection Act 1750.

${ }^{86}$ ie. the offence of 'adhering' to the enemy in the Treason Act 1351. It should be combined with the offence in a incohate stage contained in the Treason Felony Act 1848 . See n 4, article (a).

${ }^{87}$ ie material in the Offences at Sea Act 1799 and Criminal Jurisdiction Act 1802.

${ }^{88}$ ie. material in the Writ of Subpoena Act 1805.

${ }^{89}$ The Habeas Corpus Acts, see n 10, contain much obsolete material.
} 


\section{$\underline{\text { Appendix A }}$}

\section{(a) Legislation}

$\underline{\text { Statute of Westminster } 1275}$

Bearing of Armour Act 1313

Law Presentment Act 1351

Treason Act 1351 
$\underline{\text { Liberty of Subject Act } 1354}$

$\underline{\text { Justices of the Peace Act } 1361}$

\section{Observance of Due}

Process of Law 1368

$\underline{\text { Treason Act } 1495}$

Simony Acts $1588 \& 1688$

Treason Act 1695

Treason Act 1702 reformed). This crime is better covered by the law of murder in any case, as the LC indicated in 1977. Both offences have long been declared to be obsolete (since 1770);

(3) It is treason to 'compass and imagine' the death of the sovereign. This duplicates the present law on murder (including, attempt, incitement, conspiracy). With the abolition of the death penalty, there is no point in retaining both this crime and murder, since the penalty is the same (life imprisonment) and the Act of 1351 is very obscure;

(4) It is treason to wage war against the sovereign (le roi) in her realm. The last case was 1745 (Jacobite rebellion). This crime is exceedingly unlikely to occur today and it is covered by:

(a) crimes relating to knives and firearms; (b) Treason Felony Act 1848; (c) legislation against private armies and dressing in military uniform etc.

(5) It is treason to 'adhere' to the sovereign's enemies during wartime. This crime was supplemented by a Treachery Act 1940 since it was thought to be inadequate to deal with modern warfare and it depended on the accused owing allegiance to the Crown. It should be transmuted into a modern offence of treachery.

No man shall be: (a) put out of his land or tenement; (b) taken (arrested); (c) Imprisoned; (d) dis-inherited; or (e) put to death without due process. This wording repeats Magna Carta, ch 29 (extant). Such rights are also protected by the Human Rights Act 1998 (and the European Convention on Human Rights, arts 2,5,60 \& Protocol 1, art 1). There appears to be no caselaw on this Act and it was rarely cited after the abolition of the Star Chamber in 1641. The death penalty has been abolished.

It provides for 3-4 JP's for every county to be worthy men, some learned in the law. They have power to: (a) restrain, (b) pursue, (c) arrest, (d) punish, (e) require recognizances and surety. This is now covered by the Magistrates Courts Act 1980 and Justice of the Peace Act 1987 s 1 (7)..$^{90}$

No man shall be put to answer without presentment before justices or matter of record or by due process and writ. This wording repeats Magna Carta, ch 29 (still extant) and these rights are also protected by the Human Rights Act 1998 (and Convention, arts $5 \& 6$ ). There appears to be no caselaw and the Parliament Rolls indicate this wording was enacted because it repeated Magna Carta, ch 29. Presentment and writ have been abolished and matter of record is obsolete as a criminal process. As to 'due process' it also repeats the Act of 1354 (see above).

This Act excused service to a sovereign de facto on the restitution of the sovereign de jure. As the Law Commission pointed out in 1969 (LC No 22, p 40), after Parliamentary settlement of the Crown in 1688, the circumstances to which the Act was directed cannot arise. There has been no case since, at least, 1688 .

These Acts prohibit the sale of ecclesiastical (Church of England) offices. These offences are now covered by the Bribery Act 2010. There have been no cases since 1829.

Indictments for treason must be found by a grand jury within 3 years.

A crime to deprive/hinder the next in line to the throne. There appears to be no precedent and, probably, this Act has expired since it was designed to prevent a Stuart ascending the

\footnotetext{
${ }^{90}$ To the extent this latter Act does not enable JP's to bind over for good behaviour, then it should be amended. See Law Commission, Statute Law Repeals Report 2012.
} 
Treason Act 1814

Piracy Act 1837

Metropolitan Police Act 1839

Town Police Clauses Act 1847

Penal Servitude Act 1857

Malicious Damages Act 1861

$\underline{\text { Public Stores Act } 1875}$

$\underline{\text { Sheriffs Act } 1887}$

Aliens Restriction (Amendment) Act 1919

$\underline{\text { Common Informers Act } 1951}$

\section{(b) Common Law Crimes}

Common Innkeeper refusing to provide Board \& Lodging

Contempt of the Sovereign throne after Queen Anne (which did not occur). A similar provision in the Succession to the Crown Act 1707, s 1 was repealed in 1967. The wording in this Act is very obscure and too general in purport. Further, life imprisonment is too harsh for the crime, the penalty being out of sync with modern crimes. It is highly unlikely that a successful prosecution could be brought under this Act.

Removes the death penalty for treason.

S 2 imposed death penalty (now life imprisonment) for certain aggravated acts of murder. It duplicates acts under the Aviation and Maritime Security Act 1990. There is no caselaw (it seems).

Sections on driving cattle (s 54(3)), discharging canon (s 55) and rabid dogs (s 61) are all obsolete. The others are covered by firearms and animals legislation. This Act only applies to the metropolitan police district. S 79 refers to Metropolitan Police Act 1829 (rep). Thus, it is spent. S 24 imposes a fine for persons guilty of pound breach of cattle (under the law of distress) and ss 25- 7 are related thereto. They are all obsolete. S 31 relates to letting chimneys catch fire. It is obsolete, since the general law of negligence is sufficient. S 23 gives carriages permission to deviate from stage route when authorized by commissioners of carriage. It is obsolete.

S 2 substituted penal servitude for transportation. However, penal servitude was abolished by the Criminal Justice Act 1948, s 1. Thus, this Act is spent.

S 72 (offences committed within the jurisdiction of the admiralty) is spent since the only extant provisions of that Act refer to railways.

S 8 imposes fines for sweeping near dockyards, artillery ranges etc. It is obsolete. Ranges are invariably prohibited places (MOD sites). Also, shells are no longer of brass, and, thus, not worth scavaging for.

S 27(1) prohibits the sale of certain Crown offices (under sheriff, deputy sheriff etc). This is now covered by Bribery Act 2010.

S 3 imposes prison on foreigners who attempt to: (a) cause sedition or

disaffection among HM forces or civilians; or (b) promote industrial unrest. Obsolete. No caselaw (it seems). The LC (Working Paper in 1977) recommended the abolition of this Act. (a) also partly duplicates the Incitement to Disaffection Act 1934, s 1. Also, sedition was abolished as a crime in 2010.

This Act abolishes common informer actions and its repeal will not re-activate the same.

This crime only applies to common innkeepers (those who maintain hotels open to the public) who unreasonably refuse to provide board and lodging. It is exactly duplicated by civil liability. The last case in which a person was fined was in 1901 and there is no case (it seems) where an innkeeper has ever been imprisoned for this crime. It is highly unlikely a court would ever imprison for this offence. Further, there are a wide range of circumstances in which an innkeeper may reasonably refuse to provide board and lodging.

A motley assortment of quasi-treasonous crimes embracing contempts against: (a) King's Palace (fighting in it, or in or near, to the courts at Westminster); (b) King's Prerogative (refusing to assist the king for the public good, preferring a foreign prince to the king, 
Refusing to serve in a Public

Office

\section{Appendix B}

- Vagrancy Act 1824

- $\quad$ Slave Trade Act 1824

- Juries Act 1825

- Universities Act 1825

- Criminal Law Act 1826

- $\quad$ Night Poaching Act 1828

- Metropolitan Police Act 1829

- $\quad$ Game Act 1831

- $\quad$ Statutory Declarations Act 1835

- Highway Act 1835

- $\quad$ Piracy Act 1837

- Metropolitan Police Act 1839

- Metropolitan Police Courts Act 1839

- Metropolitan Police Courts Act 1840

- Railway Regulation Act 1840

- Treason Act 1842

- $\quad$ Slave Trade Act 1843

- $\quad$ Night Poaching Act 1844

- $\quad$ Town Police Clauses Act 1847

- Treason Felony Act 1848

- Indictable Offences Act 1848

- $\quad$ Admiralty Offences (Colonial) Act 1849

- Piracy Act 1850

- Criminal Justice Administration Act 1851

- Criminal Procedure Act 1853

- $\quad$ Penal Servitude Act 1857 disobeying his commands); (c) King or his Government (accusing the government of oppression or weak administration, doing an act encouraging rebellion, frightening the king into changing his decisions, spreading false rumours about him, accusing him of breaching his coronation oath, speaking contemptuously of him, refusing to pay foreign customs dues); (d) King's Title (denying it or refusing to take oaths). Offences now obsolete or are covered by civil libel, assault, battery, contempt of court. The courts no longer sit in Westminster. Last case was probably in 1703. Most cases in respect of this offence could not now be brought because of the right to free speech. Also, the sovereign is no longer involved in the making of legislation, the courts and the running of government.

The last case of this crime was in 1832 and there only seem to have been 4 published cases. This offfence is obsolete and imposing life imprisonment for such an offence is inappropriate anyway. Public offices are now paid and thus the grounds for refusal (in the past) have now gone. Under the Trade Union \& Labour Relations (Consolidation) Act 1992, s 236, a court cannot force a person to work. 
- $\quad$ Remission of Penalties Act 1859

1 section

- Metropolitan Police Act 1860

3 sections

- $\quad$ Admiralty Offences (Colonial) Act 1860

1 section

Those Acts in italics should be repealed, it is asserted.

\title{
Appendix C: Consolidating Criminal Legislation
}

\section{OFFENCES v PERSON,,${ }^{92}$ ATTEMPTS Etc}

\section{(a) Murder Etc.}

Coroners \& Justice Act 2009 (ss 54-5, murder, s 70, genocide, s 71, slavery) 4

Corporate Manslaughter \& Corporate Homicide Act $2007 \quad 25$

Suicide Act 1961 (ss 1,2, 2A, 2B) 4

Homicide Act $1957 \quad$ (ss 1-2,4) 4

Criminal Justice Act 1988 (torture, ss 134-5,8) 3

Domestic Violence, Crime and Victims Act 2004 (s 5, death of vulnerable adult) 1

Taking of Hostages Act 1982

Female Genital Mutilation Act 2003 (ss 1-6) 6

Prohibition of Female Circumcision Act 1985 (ss 1-2) 2

Offences against the Person Act $1861 \quad 41^{93}[93]$

Murder (Abolition of Death Penalty) Act 1965(spent) $\quad 00^{94}$

Piracy Act 1837 (obs) $\quad 0^{95}$

$\begin{array}{ll}\text { Piracy Act } 1850 \text { (obs) } & 0^{96}\end{array}$

\section{(b) Harassment \& Intimidation}

\author{
Administration of Justice Act 1970 (s 40, harassing debtors) \\ Malicious Communications Act 1988 (s 1, sending distressing letters) 1 \\ Criminal Justice and Police Act 2001 (ss 42, 42A, harassment in home) 2 \\ Protection from Harassment Act 1997 (ss 1-13) 9 \\ Criminal Justice and Public Order Act 1994 (s 154, intentional harassment) $\quad 1^{97}[14]$
}

\footnotetext{
${ }^{92}$ Offences v the person have been separated into: (a) murder etc; (b) harassment; and (c) children, simply for the purposes of splitting up the legislation. However, in a Crime Act, it would seem best divided into: (a) murder; (b) manslaughter; (c) suicide; (d) genocide. Then (e) slavery; (f) torture; (g) mutilation; (h) taking hostages; (i) other offences against the person (including harassment). Legislation relating to children seems ideal for a distinct category (both in the case of offences against the person and sexual crimes) since this would make reference easier.

${ }^{93} 35$ (furious driving of carriages) and s 40 (assaults on seamen) are likely obsolete. S 37 (assaulting magistrate when seeking to preserve wreck) is also likely no longer required. Ss dealing with gunpowder (ss 28-30,64-5) are likely covered by the Explosives Act 1883.

${ }^{94} \mathrm{~S} 1$ abolishes the death penalty and is spent.

${ }^{95}$ It is asserted this Act is obsolete, see GS McBain, Abolishing Obsolete Legislation on Crimes \& Criminal Procedure (2010) Legal Studies, vol 30, no 3 .

${ }^{96}$ It is asserted this Act is obsolete since, under the law of prize, perquisites are no longer distributed to privateers to ships' officers and droits of the admiralty are also obsolete since the post of Lord High Admiral has long been in abeyance (save as a sinecure). See GS McBain, Modernising the Law of Prize (to be published in the Journal of Business Law).

${ }_{97}$ Amends the Public Order Act 1986.
} 


\section{(c) $\underline{\text { Children }}^{98}$}

Domestic Violence, Crime \& Victims Act 2004 (s 5, death of child) 1

Abortion Act 1967 (ss 1-6) 6

Child Abduction Act 1984 (ss 1-10) 10

Infant Life (Preservation) Act 1929 (ss 1-2) 2

Infanticide Act 1938 (s 1) 1

Surrogacy Arrangements Act 1985 (ss 1-4) 5

Children and Young Persons Act 1933 (ss 1, 4, 11-2) $\quad 44^{99}$

Offences against the Person Act 1861 (ss 27, 58-9) $\quad 3^{100}$

Tattooing of Minors Act 1969 (ss 1-3) 3

Children and Young Persons Act 1963 (ss 37-40) $\quad 4^{101}[39]$

\section{(d) Attempts, Conspiracy, Incitement, Assisting, Concealing}

Criminal Attempts Act 1981 (ss 1-4, 6, attempts) 6

Criminal Law Act 1977 (ss 1-5 conspiracy) 5

Criminal Law Act 1967 (ss 4-5, assisting, concealing) $\quad 2^{102}$

Criminal Justice Act 1987 (s 12, conspiracy to defraud) 1

Serious Crime Act 2007 (ss 44-6,47-9) $\quad 6^{103}[20]$

A consolidating Act would likely comprise c 166 sections.

\section{Sexual \& Decency Offences}

\section{(a) Indecency \& Obscenity}

Indecent Displays (Control) Act 1981 (ss 1-4) 4

Obscene Publications Act 1959 (ss 1-4) 4

Obscene Publications Act 1964 (ss 1-2) 2

Criminal Justice and Public Order Act 1994 (ss 84-91) 7

Criminal Justice and Immigration Act 2008 (ss 63-8) 6

Coroners \& Justice Act 2009 (ss 62-8, images of children)

Criminal Justice Act 1988 (ss 160, 160A, indecent photos) 2 [32]

\section{(b) $\underline{\text { Sexual Offences }}$}

\footnotetext{
${ }^{98}$ Not included is the Adoption of Children Act 2002,s 59 (offence). It is asserted it is better left in that Act.

${ }^{99} \mathrm{~S} 1$ is cruelty to persons under 16, $\mathrm{s} 4$ is causing (or allowing) persons under 16 to be used for begging, $\mathrm{s} 11$ is exposing a child under 7 to the risk of burning, $\mathrm{s} 12$ is failing to provide for the safety of children at an entertainment.

${ }^{100} \mathrm{~S} 27$ relates to exposing children, ss 58-9 to attempts to procure abortion.

${ }^{101}$ These relate to offences of children taking part in entertainment before a certain age.

${ }^{102} \mathrm{~S} 4$ imposes penalties for assisting offenders and s 5 penalties for concealing offences or giving false information.

${ }^{103} \mathrm{~S} 44$ is the offence of intentionally encouraging or assisting an offence, s 45 is encouraging or assisting an offence believing that it will be committed,s 46 is encouraging or assisting offences believing that one or more will be committed. It may be noted that s 59 abolished the common law offence of inciting the commission of another offence.
} 
Street Offences Act 1959 (ss 1, 1A, 4, loitering or solicitings) 2

Children and Young Persons (Harmful Publications) Act 1955 (ss 1-4) 4

Criminal Law Act 1977 (s 54, incitement of girls under 16) 1

Protection of Children Act 1978 ( ss 1-7) 7

Sexual Offences Act 1956 (ss 33-7, brothels) 5

Sexual Offences Act 1967 (s 6, premises for homosexual practices) 1

Sexual Offences (Amendment) Act 1992 (ss 1-6) 6

Sexual Offences (Conspiracy and Incitement) Act 1996 (ss 2-3,5) 3

Sexual Offences (Amendment) Act 2000 (ss 1-6) 6

$\begin{array}{ll}\text { Sexual Offences Act } 2003 & 174\end{array}$

Children and Young Persons Act 1933 (ss 3, children in brothels) 1

Sexual Offences (Protected Material) Act 1997 (s 8, not yet in force) $\quad 1^{104}$ [213]

Criminal Justice and Police Act 2001 (ss 46-7, ad re prostitution) 2

Sexual Offences (Amendment) Act 1976 (spent) 0

Sexual Offences Act 1993 (spent) $\quad 0^{105}$

A consolidating Act would likely comprise c 245 sections. It would simply be a matter of integrating earlier sexual offences into the Sexual

Offences Act 2003.

\section{OFFENCES V PROPERTY \& FINANCIAL CRIMES}

\section{(a) $\underline{\text { Property }}$}

$\begin{array}{ll}\text { Computer Misuse Act } 1990 & 10\end{array}$

Criminal Damage Act 1971 (ss 1-7, 9-10) 9

Criminal Law Act 1977 (entering/remaining on property, ss 6-12A)

Police and Justice Act 2006 (computer misuse s 38, transitional) 1

Malicious Damage Act 1861(ss 35-6, 58 - railways) $\quad 3^{106}$

$\begin{array}{ll}\text { Public Stores Act } 1875 & 10^{107}\end{array}$

Theft Act 1968

Theft Act 1978 (ss 3-4) 2

Unsolicited Goods and Services Act 1971

Legal Aid, Sentencing and Punishment of Offenders Act 2012 (s 144, re squatters) $\quad 1^{108}$

Mobile Telephones (Re-Programming) Act 2002(ss 1-2) 2

Criminal Justice and Public Order Act 1994 (ss 61-3,68-9,77-8) $\quad 7^{109}$ [96]

\section{(b) Financial Crimes}

\footnotetext{
${ }^{104}$ Some of the ss could be located under Criminal Procedure.

${ }^{105}$ This Act is spent, since $\mathrm{s} 1$ abolishes the presumption of sexual incapacity.

${ }^{106} \mathrm{~S} 72$ (jurisdiction of the admiralty) is obsolete since no admiralty provisions remain in the Act.

${ }^{107}$ S 8 (prohibition on sweeping etc) is obsolete. See GS McBain, Abolishing Obsolete Legislation on Crimes \& Criminal Procedure (2010) Legal Studies, vol 30. No 3.

${ }^{108} \mathrm{~S} 144$ is squatting in a residential building.

${ }^{109}$ These relates to public order offences committed by trespassers on land (ss 61-3), aggravated trespass (ss 68-9) and unauthorised campers (ss 77-8).
} 
Bribery Act 2010

Forgery Act 1861 (ss 34,recognizances, 36-7, births etc registers) 3

Forgery and Counterfeiting Act 1981 (ss 1-10,14-22,24-5,27-8) 25

Fraud Act 2006 (ss 1-9, 11-3) 12

Criminal Justice Act 1993 (ss 52-64, insider dealing) 13

Debtors Act 1869 (s 13, fraudulently obtaining credit) 1

Documentary Evidence Act 1868 (s 4, forgery) $\quad 1^{110}$

Documentary Evidence Act 1882 (s 3, forgery) 1

Criminal Justice Act 1925 (s 36, forgery of passport, s 37 pension documents) 2

Evidence Act 1851 (s 15, certifying a false document) 1

Criminal Justice Act 1991 (s 20A, false statements as to financial circs) 1

Honours (Prevention of Abuses Act) 1925 (s 1) 1 [78]

Simony Acts $1588 \& 1688 \quad 0^{111}$

A consolidating Act would likely comprise c. 166 sections.

\section{Offences v Public Order}

\section{(a) Official Secrets}

Official Secrets Act 1911 (ss 1,3,6-8,10) $\quad 6^{112}$

Official Secrets Act 1920 (ss 1-3, 6-8) 6

Official Secrets Act 1989

Official Secrets Act 1939 (spent) $\quad 0^{113}$ [27]

\section{(b) $\underline{\text { Terrorism }}$}

$\begin{array}{lll}\text { Terrorism Act } 2000 \quad \text { (ss 11-3, 54-63) } & 7^{114}\end{array}$

Terrorism Act 2006 (ss 1-20) 21

Prevention of Terrorism Act 2005 (s 9, control orders) 1

Criminal Law Act 1977 (s 51, bomb hoaxes) 1

Suppression of Terrorism Act 1978 (spent) $\quad 0$ [30]

\section{(c) Other}

Criminal Jurisdiction Act 1802 (s 1, public service crimes abroad) $\quad 1^{115}$

Criminal Justice Act 1948 (s 31, Crown servant abroad)

Foreign Enlistment Act 1870 (ss 2,4-30,32) 29

${ }^{110} \mathrm{~S} 4$ relates to the forgery of certain documents. S 3 is spent (there are no longer colonies or possessions with official secrets legislation pre 1911).

${ }^{111}$ It is asserted these Acts have been replaced by the Bribery Act 2010. They should be repealed, therefore. For the same reason, the Sheriffs Act 1887, s 27(1) should be repealed.

${ }^{112} \mathrm{~S} 11$ is obsolete (law in British possessions prior to Act).

${ }^{113}$ This Act is spent, it amends the Official Secrets Act 1920.

${ }^{114}$ Ss 11-3 relate to terrorist membership, support and uniforms. The other ss concern training.

${ }^{115}$ Relates to crimes committed in public service. The wording concerning laying in Middlesex is obsolete. 
Incitement to Disaffection Act 1934 (s 1, seducing HM forces member)

Police and Justice Act 2006 (ss 68-9)

Treason Act 1351

Treason Act 1495

Treason Act 1695

Treason Act 1702

Treason Act 1814

Treason Act 1842

Treason Felony Act 1848

Aliens Restriction (Amendment) Act 1919 (s 3, sedition)

Bearing of Armour Act 1313

Statute of Westminster 1275(intimidation at elections)

$3^{116}$
$2^{117}[36]$
$0^{118}$
$0^{119}$
$0^{120}$
$0^{121}$
$0^{122}$
$0^{123}$
$0^{124}$
$0^{125}$
$0^{126}$
$0^{127}$

$3^{116}$ $2^{117}[36]$

$0^{11}$

12

$0^{122}$

$0^{12}$

$0^{125}$

$0^{126}$

\section{(d) Public Order}

Metropolitan Police Act 1839

$16^{128}$

Public Meeting Act 1908 (s 1, endeavour to break up meeting)

1

4

34

6

5

1

$5^{129}$

1 [73]

$0^{130}$

0

Public Order Act 1963(spent)

\section{(e) Racial Hatred}

\footnotetext{
${ }^{116}$ Ss 2(3) and (4) are unnecessary, being covered by more modern legislation re searching of women and disposal of seized property.

${ }^{117} \mathrm{~S} 68$ relates to the disclosure of information to prevent crime and $\mathrm{s} 69$ is the offence of disclosing protected information which has been disclosed by a public authority.

${ }^{118}$ It is asserted this Act should be repealed, save for the provision on 'aiding' which should become an offence of treachery. See GSMcBain, Abolishing the Crime of Treason (2007) 81 ALJ 94-134. If the Treason Acts are repealed, so too will be the Forfeiture Act 1870 s 2 (forfeiture of office on conviction for treason).

${ }^{119}$ If the 1351 Act is repealed, so will this one.

${ }^{120}$ If the 1351 Act is repealed, so will this one.

${ }^{121}$ It is asserted this Act is obsolete.

${ }^{122}$ If the 1351 Act is repealed so will this one.

${ }^{123}$ Relates to assaults on the sovereign. It needs to be modernised.

${ }^{124}$ It is asserted this Act should be modernized. See GS McBain, Abolishing the Crime of Treason Felony (2007) 81 ALJ 812-38.

${ }^{125}$ It is asserted this offence is obsolete (it may also be noted that seditious libel has been abolished).

${ }^{126}$ It is asserted this offence is obsolete.

127 Ibid.

${ }^{128}$ S 79 refers to the Metropolitan Police Act 1829 (rep) and is spent. A number of other offences are likely obsolete such as: discharging canon (s 55), mad dogs (s 61), stage carriages deviating from route (s 53), forbidden fairs (s 38). See GS McBain, Abolishing Obsolete Legislation on Crimes \& Criminal Procedure (2010) Legal Studies, vol 30. No 3.

129 These relate to trespass in a designated area (s 128) and in the vicinity of Parliament (ss 132-6).

${ }^{130}$ It is asserted all these minor offences are obsolete. In the case of stray cattle (ss 24-7), accidently allowing chimneys to catch fire (s 29 ), drunks at police stations (s 31), bear baiting \& cock fighting (s 36) and deviating carriages (see s 23), see McBain, n 38. Licensed hackney carriages (ss 37-66,68) are now regulated by statute (see legislation on London cabs etc, McBain, Time to Abolish the Common Carrier, [2005] Journal of Business Law, Sept 545-96 at pp 582-4 ). Coffee shop keepers harbouring disorderly persons (s 35) is also obsolete. See also Metropolitan Police Act 1839, s 44).
} 
Crime and Disorder Act 1998 (ss 28-33, 96, racial)

6

Racial \& Religious Hatred Act 2006 (amends only)

$0^{131}[6]$

\section{(f) Justice}

\section{(i) Courts [This is probably better placed in a Criminal Procedure Act]}

Contempt of Court Act 1981 (s 12, magistrates courts) 1

Criminal Justice and Police Act 2001 (ss 39-41, intimidating/harming witnesses) 3

Criminal Justice Act 1967 (s 89, false statements tendered in evidence) 1

Criminal Justice Act 1987 (s 11A, offences re reporting) 1

Witnesses (Public Inquiries) Protection Act $1892 \quad$ (s 2, obstructing witnesses) $\quad 5^{132}$

Criminal Justice and Public Order Act 1994 (s 51, intimidating witness/jurors) 1

Criminal Justice Act 2003 (s 72, offence re reporting on criminal matters) 1

Youth Justice and Criminal Evidence Act 1999 (ss 49-51) $\quad 3^{133}$

$\begin{array}{ll}\text { Perjury Act } 1911 & 14[30]\end{array}$

(ii) Police \& Sheriffs [This is probably better placed in a Police Act]

Police Act 1996 (ss 89-91, assault, impersonation,disaffection) $\quad 3^{134}$

Police Act 1997 (ss 123-4, police criminal records) 2

Sheriffs Act 1887 (s 29, misconduct by sheriffs) $\quad 1^{135}$

Statutory Declarations Act 1835 (s 13, JP administering oath) $\quad 0^{136}[6]$

\section{(iii) Prisons [This is probably better placed in a Prison Act]}

Prisoners (Return to Custody) Act 1995 (s 1, remaining at large) $\quad 1^{137}$

Prison Act 1952 (ss 39-41, escape and contraband) $\quad 3^{138}$

Prison Security Act 1992 (ss 1-2, mutiny \& escape) 2

Criminal Justice Act 1961 (s 22, assisting escape) 1

Prison Security Act 1992 (s 1, prison mutiny) $1[8]$

In conclusion, a consolidating Act would likely comprise c. 226 sections (182 sections, if material relating to the courts, police and sheriffs and prisons, were placed in those Acts). It is asserted that the following material should also be contained in a Public Order Act:

\footnotetext{
${ }^{131}$ This amends other legislation.

${ }^{132}$ In modern times, it is not clear whether ss 3-5 are needed.

${ }^{133}$ This relates to offences against reporting restrictions.

${ }^{134} \mathrm{~S} 89$ relates to assaulting a police officer; s 90 to impersonation and s 91 to causing disaffection.

${ }^{135} \mathrm{~S} 29$ punishment for misconduct. It is asserted that s 27 (sale of offices) is obsolete, the matter now being covered by the Bribery Act 2010 .

${ }^{136}$ It is asserted this section is obsolete. See McBain, $\mathrm{n} 38$.

${ }^{137} \mathrm{~S} 1$ is the offence of remaining at large after temporary release.

${ }^{138}$ s 39 (assisting prisoners to escape), s 40 (unlawful conveyance of spirits), s 41 (unlawful introduction of other articles).
} 


\section{Weapons, Explosives, Drugs, Alcohol, Vehicles, Sports}

\section{(a) Weapons - General}

Prevention of Crime Act 1953 (s 1-1A,offensive weapons) $\quad 2^{139}$

Legal Aid, Sentencing and Punishment of Offenders Act 2012 (s 142) 140

Criminal Justice Act 1988 (ss 139-42, blades/weapons) 9

Violent Crime Reduction Act 2006 (ss 28-9, minding a weapon) 2

Criminal Justice and Public Order Act 1994 (s 60, stopping re offensive weapons) $\quad 1^{141}[15]$

\section{(b) Firearms}

Firearms Act $1968 \quad 71$

Firearms Act 1982 (ss 1-2, imitation firearms) 2

Firearms (Amendment) Act $1988 \quad 26$

Firearms (Amendment) Act 1997(ss 1-8,15-8,32-6,39,44-5,48) $22^{142}$

Violent Crime Reduction Act 2006 (ss 32,35-8) 5 [126]

Firearms (Amendment) Act 1994 (amends) 0

Firearms (Amendment) (No 2) Act 1997

\section{(c) Knives \& Others}

Crossbows Act 1987 (ss 1-3A)

Knives Act 1997 (ss 1-10) 10

Restriction of Offensive Weapons Act 1959 (s 1, knives) $\quad 1^{143}[16]$

\section{(d) Explosives \& Toxins}

Cluster Munitions (Prohibition) Act $2010^{144}$

Explosive Substances Act 1883 (ss 2-9)

Explosives Act 1875 (ss 31, fireworks, s 80, selling gunpowder)

Fireworks Act 2003 (s 11, offences against regulations)

Landmines Act 1998*

Anti-Terrorism, Crime and Security Act 2001(nuclear, ss 47-57, 67, 113-5)*

Nuclear Explosion (Prohibition and Inspection) Act 1998 (not yet in force)*

Nuclear Material (Offences) Act 1983*

31
$2^{146} 7^{145}$
$1[41]$
28
$14^{147}$
14
10

\footnotetext{
${ }^{139} \mathrm{~S} 1$ (prohibition of the carrying of offensive weapons without lawful authority). S $1 \mathrm{~A}$ is the offence of threatening with an offensive weapon in public.

${ }^{140} \mathrm{~S} 142$ is the offence of threatening with a blade or point or offensive weapon or on school premises.

${ }_{141} \mathrm{~S} 60$ relates to stopping pedestrians or vehicles to search for offensive weapons).

142 Offences relating to gun barrels in the Gun Barrel Acts 1868, 1950 \& 1978 are best left in the same.

${ }^{143}$ The Act is extended to NI by the Protection of Offensive Weapons Act 1961, s 2.

${ }^{144} \mathrm{~S} 2$ contains the criminal offence.

145 The process of inquiry by the A-G (s 6) and of no procedure prior to A-G's leave (s 7), relate to Victorian times and bombing by Fenians in Ireland and the mainland (see also McBain, $\mathrm{n} 4$ re treason felony). It is asserted they are not required now and that the the police should simply proceed as a matter of course - as they would do in the case of gunpowder offences.

${ }^{146} \mathrm{~S} 80$ imposes a penalty for throwing fireworks in a thoroughfare, s 31 imposes a penalty for the sale of gunpowder to children.

${ }^{147} \mathrm{~S} 67$ relates to toxins, ss 113-5 to dangerous substances.
} 
Biological Weapons Act 1974*

Chemical Weapons Act 1996
5

38 [109]

*Those with an * being of a rather rarer nature and containing much procedure would probably best left out of a Crime Act, but could be consolidated in a separate Act.

\section{(e) Drugs}

Drug Trafficking Act 1994 (ss 39-40,55-59A,60-1,63)

10

Drug Trafficking Offences Act 1986 (ss 32-4)

2

Drugs Act 2005

11

$8^{148}$

$6[37]$

Drug Trafficking Act 1984 (ss 55-59A)

\section{[37]}

\section{(f) Alcohol}

Criminal Justice Act 1967 (s 91, drunk in public place) $\quad 1$

Intoxicating Substances (Supply) Act 1985 (s 1) 1

Licensing Act 1872 (s 12, persons found drunk) 1

Licensing Act 1902 (s 2, drunk in charge of child) $\quad 1^{149}$

Penalties for Drunkenness Act 1962 (s 1, increased penalties) 1

Sporting Events (Control of Alcohol etc) Act 1985 (s 8) 8

Children and Young Persons Act 1933 (s 5, liquor to children) 1

Policing and Crime Act 2009 (s 30, alcohol in a public place) $\quad 1^{150}$

Metropolitan Police Act 1939 (s 44, permitting drunkenness) $\quad 1^{151}$

Licensed Premises (Exclusion of Certain Persons) Act 1980

Licensing Act 2003 (ss 136-59) $25^{153}$

Criminal Justice and Public Order Act 2001 (s 12(4)) $\quad 1^{154}$ [46]

\section{(g) Vehicles}

Criminal Justice Act 1972 (s 24, vehicle used for purpose of crime)

Vehicle (Crime) Act 2001 (s 39, bodies corporate) 1

Legal Aid, Sentencing and Punishment of Offenders Act 2012 (s 143) ${ }^{155} \quad 1$

Criminal Attempts Act 1981 (s 9, interference with vehicles) 1

Criminal Justice and Public Order Act 1994 (s 167, touting for car hire) 1

Aggravated Vehicle Taking Act 1992

\footnotetext{
${ }^{148}$ The Controlled Drugs (Penalties) Act 1985 amends this Act.

${ }^{149} \mathrm{~S} 1$ (apprehending a drunk in a public place) \& s 6 (prohibition of sale of liquor to habitual drunks), are matters of criminal procedure, see Criminal Procedure.

${ }^{150} \mathrm{~S} 30$ is the offence of persistently possessing alcohol in a public place.

${ }^{151}$ This relates to a penalty on refreshment house keepers for permitting drunkenness.

152 Subject to prospective repeal.

${ }^{153}$ Ss 136-9 relate to unauthorized licensable activities, ss 140-3 to drunkenness and disorderly conduct, ss $145-54$ to children and alcohol, ss 156-7 to vehicles and trains, s 158 to false statements. S 159 is interpretation.

${ }^{154}$ This relates to consuming alcohol in a designated public place.

${ }^{155} \mathrm{~S} 143$ is causing serious injury by dangerous driving.
} 


\section{(h) $\underline{\text { Sports }}$}

Football (Offences) Act $1991 \quad 5$

Football Spectators Act 1989 (ss 14J, 24) $22^{156}$

Criminal Justice and Public Order Act 1994 (s 166 \& 166A) $\quad 2^{157}$

Sporting Events (Control of Alcohol) Act 1985

In conclusion, a consolidating Act would likely comprise c 418 sections (but only 294 sections if the material with an *is removed).

\section{Grand Conclusion}

No of Acts on Criminal Legislation:

No of Sections on:

$\begin{array}{ll}\text { Offences v the Person, Attempts etc } & 166 \\ \text { Sexual \& Decency Offences } & 245 \\ \text { Property Offences \& Financial Crimes } & 166 \\ \text { Offences v Public Order } & 226 \text { (or 182) } \\ \text { Weapons, Explosives, Drugs, Alcohol, Vehicles, Football } & 418 \text { (294 if* excluded) }\end{array}$

Total Sections (if all combined): 1211 (or 1043 if with Acts marked with * in heading Public Justice). Note: Legislation Not Included : Slave Trade Acts $1824,1843 \& 1873$.

\section{Appendix D: Consolidating Criminal Procedure Legislation}

\section{(a) $\underline{\text { Accessories }}$}

Accessories and Abettors Act 1861 (s 8, abettors)

\section{(b) Appeals}

Criminal Appeal Act 1968 (appeal to Court of Appeal and HL) 51

Criminal Appeal Act 1995

Administration of Justice Act 1960 (ss 1-6, \& 9, appeals to HL) 8

Criminal Justice Act 1972 (s 36, appeal to CA following acquittal) 1

Criminal Justice Act 2003 (ss 57-74, prosecution appeals) 17 [103]

\section{(c) $\underline{\text { Arrest }}$}

\footnotetext{
${ }^{156}$ See also s 22 (restriction orders). The Football (Offences and Disorder) Act 1999 amends this Act.

${ }^{157}$ Offence of unauthorized sale of football tickets.

${ }^{158} \mathrm{~S} 8$ deals with abettors in misdemeanours (abettors to be punished same as principals).
} 


\section{(d) $\underline{\text { Bail }}$}

Bail Act 1976

Bail (Amendment) Act 1993 (s 1, prosecution right of appeal) 1

Criminal Justice Act 1948 (s 37, bail) 1

Criminal Justice Administration Act 1914 (s 19, continuous bail) 1

Criminal Justice and Public Order Act 1994 (s 25, bail re homicide and rape) $\quad 1$

Criminal Justice Act 1967 (ss 20, 22, re bail) 2

Criminal Justice and Immigration Act 2008 (ss 51-2) $\quad 2^{159}$

Coroners \& Justice Act 2009 (s 115, bail decisions in murder cases)

Criminal Justice Act 2003 (ss 16, 17, 21, appeals to HC and CC) 3 [29]

(e) Committal, Transfer, Sending for Trial

Criminal Law Amendment Act 1867 (s 10, delivery up)

(f) Compensation

Criminal Justice Act 1948 (s 133, 133A, 133B, miscarriage of justice)

Crime and Security Act 2010 (ss 47-54, compensation of victims)

\section{(g) Contempt of Court}

Contempt of Court Act 1981 (ss 14-7)

\section{(h) Costs}

Administration of Justice Act 1970 (s 41, recovery of costs, magistrates) 1

Prosecution of Offences Act 1985 (ss 16-21, costs) $5[6]$

\section{(i) Courts}

Children and Young Persons Act 1933 (ss 45-9, youth courts)

Criminal Justice Act 1925 (s 41, taking photos in court)

\section{(j) Criminal Injuries Compensation}

\footnotetext{
${ }^{159} \mathrm{~S} 51$ relates to bail conditions, s 52 is in respect of bail for summary offences.

${ }^{160} \mathrm{~S} 10$ enables a prison governor to deliver up a person indicted without a court order.
} 


\section{(k) Criminal Evidence}

Criminal Evidence Act 1898 (ss 8-10)

Criminal Justice Act 1948 (ss 41-2, evidence by certificate/order of speeches)

Evidence Act 1851 (ss 3, 13)

Prevention of Crimes Act 1871 (s 18, evidence of previous conviction)

Criminal Justice Act 1967 (ss 8-10)

Police and Criminal Evidence Act 1984 (ss 71-2, 73-82)

Criminal Evidence (Amendment) Act 1997 (ss 1-2, body samples)

Criminal Justice Act 1972 (s 46, admissibility of written statements) 1

Criminal Procedure Act 1865 (s 2, summing up of evidence in felony etc) 1

Criminal Justice Act 2003 (ss 98-113, evidence, 114-35, hearsay) 37

Children and Young Persons Act 1963 (s 26, medical certificate re condition) 1 [66]

(I) Criminal Procedure - General

\section{(i) General}

Criminal Justice Act 1987 (ss 4-10, transfer of cases to CC, preparatory hearings) $\quad 8$

Criminal Procedure and Investigation Act 1996

Prosecution of Offences Act 1985 (ss 22-22B,23-6, proceedings) 8

Criminal Justice Act 1925 (ss 33, procedure re corporations) 1

Sexual Offences (Protected Material) Act 1997 (ss 1-7, not yet in force) 7

Children and Young Persons Act 1933 (ss 31,34, 34A,36, 39,41-4, 50, 59) 10

Children and Young Persons Act 1963 (s 26, medical cert) $\quad 2^{165}$

Criminal Law Act 1967 (ss 1,6,9,14) $\quad 4^{166}$

Coroners and Justice Act 2009 (ss 74-85, anonymity in investigations, 104) $16^{167}$

Criminal Justice and Immigration Act 2008 (s 53) $\quad 1^{168}$

Criminal Justice Act 1948 (ss $39 \& 41) \quad 2 \quad 2^{169}$

Youth Justice and Criminal Evidence Act 1999 (ss 41-3, protection re sexual offences) $\quad 1^{170}$

Law Reform (Year and a Day Rule) Act 1996 (s 2, fatal offence proceedings) $\quad 1^{171}$

Serious Crimes Act 2007 (ss 52-7, jurisdiction and procedure) 6

Criminal Justice Act 2003 (ss 43-50, trials on indictment without jury) 7 [151]

\footnotetext{
${ }^{161} \mathrm{~s} 2$ evidence of person charged, s 3 right of reply, s 6 provisions as to previous Acts.

${ }^{162}$ S 3 provides that nothing shall compel a person charged with a criminal offence to give evidence which tends to incriminate himself. S 13 , where necessary to prove the conviction or acquittal of a person charged, it is not necessary to produce a record.

${ }^{163} \mathrm{~S} 8$ is proof of criminal intent, s 9 is proof by written statement, $\mathrm{s} 10$ is proof by formal admission.

${ }^{164}$ Concerns convictions and acquittals (ss 73-5), confessions (ss 76-7) etc. Ss 71-2 relate to microfilm.

${ }^{165} \mathrm{~S} 18$ relates to jurisdiction in respect of magistrates' courts, s 29 relate to persons between 17 and 18 .

${ }^{166} \mathrm{~S} 1$ abolishes the distinction between felony and misdemeanor, s 6 relates to the trial of offences, s 9 to pardon, s 14 is civil rights in respect of maintenance and champerty.

${ }^{167}$ Ss 74-55 relate to anonymity in investigations. S 104 is the examination of the accused through an intermediary.

${ }^{168} \mathrm{~S} 53$ relates to the allocation of offences triable either way.

${ }^{169}$ S 39 provides that common assault and battery are to be summary offences, s 41 provides for a power of the Crown Court to deal with summary offences.

${ }^{170}$ Ss 41-3 relate to the protection of the complainant in proceedings for sexual offences.

${ }^{171}$ Only s 2 is not obsolete (restriction on institution of proceedings for a fatal offence).
} 


\section{(ii) Court Process}

Criminal Justice Act 1967 (s 17, verdict of not guilty by order of judge)

Domestic Violence, Crime and Victims Act 2004 (ss 17-21, trial by jury on sample counts)1

Criminal Justice and Public Order Act 1994 (ss 34-9, inference from accused's silence) 6

Criminal Procedure (Right of Reply) Act 1964 (s 1, trials on indictment)

Criminal Procedure Act 1853 (s 9, bringing up prisoner to give evidence)

Criminal Procedure Act 1865

\section{(iii) $\underline{\text { Jurisdiction }}$}

Offences at Sea Act 1799 (s 1, criminal offences at sea)

Territorial Waters Jurisdiction Act 1878 (criminal offences in such waters)

\section{(iv) Obsolete}

None to put to answer without due process 1368 (obs)

Law Presentment Act 1351

Liberty of Subject Act 1354

Common Informers Act 1951(obs)

\section{(m) $\underline{\text { Crown Prosecution Service }}$}

\section{(n) $\underline{\text { Debtors }}$}

Debtors Act 1869 (ss 4-6,8, 10)

Administration of Justice Act 1970 (s 11, power of committal)
$5^{180}$

\section{(o) Extradition}

\footnotetext{
${ }^{172} \mathrm{~S} 1$ is the right of reply at trials on indictment.

${ }^{173} \mathrm{~S} 9$ provides that the Secretary of State may issue a warrant for bringing up a prisoner (not in custody under civil process) to give evidence.

${ }^{174}$ This relates to summing up of evidence in cases of felony and misdemeanor etc.

${ }^{175}$ Provides that all offences at sea are to be tried in the same manner as offences on land.

${ }^{176} \mathrm{It}$ is asserted this provision of criminal procedure is obsolete, GS McBain, Abolishing Obsolete Legislation on Crimes \& Criminal Procedure (2010) Legal Studies, vol 30. No 3, p 9-12.

${ }^{177}$ Ibid.

${ }^{178}$ Ibid.

${ }^{179}$ The law generally on common informers should be abolished.

${ }^{180} \mathrm{~S} 4$ abolishes imprisonment for debt with exceptions, s 5 is a power to commit for small debts, $\mathrm{s} 6$ is a power to arrest, $\mathrm{s} 8$ is a saving for the sequestration of property, s 10 defines 'prescribed'.

${ }^{181}$ This relates to the power to commit under the Debtors Act 1869.
} 


\section{(p) $\underline{\text { Fines \& Penalties }}^{182}$}

Criminal Justice Act 1982 (ss 37-40, 46-8) $\quad 7^{183}$

Remission of Penalties Act 1859 (s 1, offences remitted by Crown) $\quad 1^{184}$

Criminal Justice Act 1988 (s 92, increase of fines) 1

Crime (Sentences) Act 1997 (ss 35, 40, fines for defaulters) 2

Criminal Justice and Immigration Act 2008 (ss 77-8) $\quad 1^{185}$

Criminal Justice Act 1967 (s 92, increase in fines) 1

Criminal Justice and Public Order Act 1994 (s 157, increase in penalties) 1

Criminal Justice Act 1993 (ss 65 \& 70, fixing of fines under implementing regs) $\quad 115]$

\section{(q) Forfeiture}

Forfeiture Act $1870 \quad$ (s 1, forfeiture for treason) $\quad 2^{186}$

Forfeiture Act 1982

\section{(r) Habeas Corpus}

Administration of Justice Act 1960 (ss 14-5, habeas corpus)

\section{(s) Indictments}

Administration of Justice (Misc Provs) 1933 (s 2, indictment of offenders)

Indictments Act 1915

Criminal Justice Act 1948 (s 40)

\section{(t) Indictable Offences}

Criminal Justice 1948 (s 31, indictable offences abroad)

\section{(u) Insanity}

Criminal Cases Review (Insanity) Act 1999

Criminal Procedure (Insanity) Act $1964 \quad 6$

Criminal Procedure (Insanity and Unfitness to Plead) Act $1991 \quad 1$

Trial of Lunatics Act 1883 (s 2, guilty but insane) 1 [10]

\footnotetext{
${ }^{182}$ A consolidation Act would set out the latest fine schedule.

${ }^{183}$ Relates to the standard scale of fines (ss 37, 46-8) and increases (ss 38-40).

${ }^{184} \mathrm{~S} 1$ provides that penalties for offences may be remitted by the Crown, although payable to persons other than the Crown.

${ }^{185}$ Ss 77-8, power to alter penalty for unlawfully obtaining personal data.

${ }^{186} \mathrm{~S} 2$ provides that a conviction for treason or felony is likely to be a disqualification for offices. Felonies have been abolished. S 4 provides for a maximum award of $£ 100$ for persons defrauded or injured by a felony. It is very likely obsolete.

${ }^{187} \mathrm{~S} 10$ provides that persons in custody and also recognizances may be brought up without habeas corpus.

${ }^{188} \mathrm{~s} 40$ provides for a power to join in an indictment a count for assault.

${ }^{189} \mathrm{~S} 31$ relates to jurisdiction and procedure in respect of certain indictable offences committed abroad.
} 


\section{(v) Police - inc Police Power \& Detention**}

Criminal Justice Act 1972 (s 34, drunken offenders to treatment centre) $\quad 1$

Universities Act $1825^{190}$ (Cambridge University Police) 2

Imprisonment (Temporary Provisions) Act $1980 \quad$ (s 6, imprisonment by constable)

Constables Protection Act $1750 \quad 11^{191}$

Criminal Justice Act 1948 (s 66, legal custody by constable) $\quad 1$

Metropolitan Police Act 1839 (s 33, police may board vessels) 1 [7]

** This material could be put in a Police Act (see Criminal Justice).

\section{(w) Prisons}

Offender Management Act 2007

Prison Act $1952 \quad 38$

Criminal Justice Act 1972 (s 60, power to enter re acquisition of land) $\quad 1^{193}$

Criminal Justice Act 1961 (ss 23-4, 35, 37) $\quad 4^{194}$

Coroners and Justice Act 2009 (ss 113, offenders assisting investigations) 1

Criminal Justice Act 1948 (s 123, young offenders) 1

Criminal Justice Act 1991 (ss 84-92, contracted out prisons and functions) 8

Criminal Justice Act 1948 (s 167, acquisition of easements under Prison Act 1952) 1

Criminal Justice and Public Order Act 1994 (ss 93-128A) 1 [93]

** This material could be put in a Prisons Act (see Criminal Justice).

\section{(x) Prisoners \& Offenders}

Rehabilitation of Offenders Act 1974

Repatriation of Prisoners Act 1984

Crime and Disorder Act 1998 (s 101, early release) 1

Criminal Justice Act 1967 (ss 70-2) $\quad 33^{195}$

Legal Aid, Sentencing and Punishment of Offenders Act 2012 (ss 108-31) $10^{196}$

Children and Young Persons Act 1933 (s 58) $\quad 1^{197}$

Criminal Justice Act 1982 (s 32, early release of prisoners) 1

Criminal Justice and Public Order Act 1994 (ss 150-3, release on licence etc) 4

Criminal Justice and Court Services Act 2008 (ss 62,64, release on licence) 2

Crime (Sentences) Act 1997 (ss 41-2, transfer of prisoners) 2

\footnotetext{
${ }^{190}$ This Act is obsolete vis a vis Oxford university since they no longer have a university constabulary.

${ }^{191}$ See text.

${ }^{192}$ Ss 1-15 (new arrangements for the provision of probation services), 16-27 (prisons), 28-33 (other provisions about the management of offenders).

${ }^{193} \mathrm{~S} 60$ (power of entry in connection with acquisition of land for prisons).

${ }^{194}$ Ss 23-4 concern prison rules and the management of prisons, ss 35-7 relate to legal custody and prison governors' reports.

${ }^{195} \mathrm{~S} 70$ relates to prison transfer, $\mathrm{s} 71$ to powers of release, $\mathrm{s} 72$ to the power of magistrates to issue warrants for escaped prisoners.

${ }^{196}$ Covers release on licence (ss 108-21), dangerous offenders (ss 122-8), prisoners (ss 19-31), offenders (ss 139-40).

${ }^{197} \mathrm{~S} 58$ provides for the power of the Secretary of State to send certain juvenile offenders to approved schools.
} 
Prisoners (Return to Custody) Act 1995 (s 1, at large after temp release)

Prisoners Earnings Act 1996 (ss 1-4)

Criminal Justice Act 1991 (ss (33-51, early release, ss 80-3, escorts)

Criminal Justice (International Cooperation) Act 1990 (ss 5-6)

Criminal Justice Act 2003 (ss 224-35, 237-68, 269-77,325-7B)

** This material could be put in a Prisons Act (see Criminal Justice).

\section{(y) Proceeds of Crime}

Proceeds of Crime Act 2002

$457[457]$

\section{(z) Recognizances}

Criminal Justice Administration Act 1914 (s 24, mode of entering into)

1[1]

\section{(aa) Remand}

Legal Aid, Sentencing and Punishment of Offenders Act 2012 (ss 97-107)

Criminal Justice Act 1948 (ss 27 \& 49, remand \& remand homes)

Crime and Disorder Act 1998 (ss 97-8, remand)

Children and Young Persons Act 1933 (ss 77,79-81)

\section{(bb) $\underline{\text { Reporting }}$}

Judicial Proceedings (Regulation of Reports) Act 1926

Criminal Justice (Amendment) Act 1981 (s 1, committal proceedings)

Children and Young Persons Act 1933 (ss 45-9, youth courts)

Criminal Justice Act 1987 (s 11 restriction on reporting)

Criminal Justice Act 1988 (s 159, reports of proceedings)

Youth Justice and Criminal Evidence Act 1991 (ss 44-8, reporting restrictions)

Sexual Offences (Amendment) Act 1976 (ss 3-4, reporting, anonymity etc)

Criminal Justice Act 2003 (ss 51-6)
1

4

30

$2^{198}$

$58^{199}[146][263]$

\section{(cc) $\underline{\text { Rewards }}$}

Criminal Law Act 1826 (ss 28-9, apprehending offenders)

$2^{202}[2]$

\footnotetext{
${ }^{198}$ S 5 provides for the transfer of a UK prisoner to give evidence or assist at an investigation. S 6 relates to the transfer of an overseas prisoner to give evidence or assist at an investigation in the UK.

${ }^{199}$ Ss 224-35 relate to dangerous offenders, 237-68 relate to release on licence, 269-77 to the effect of a life sentence, sss $325-7 \mathrm{~B}$, to assessing risks posed by sexual or violent offenders).

${ }^{200} \mathrm{~S} 77$ makes provision re remand homes. Ss 79-81 relate to approved schools.

${ }^{201}$ Relates to publication of reports of judicial proceedings.

${ }^{202}$ Ss 28-9 (court may order compensation to be paid to those who have been active in the apprehension of certain offenders).
} 


\section{(dd) Sentencing}

Crime (Sentences) Act 1997 (ss 28,30-2B, 34, life sentences) 8

Powers of Criminal Courts (Sentencing) Act 2000 (ss 118-41) 23

Legal Aid, Sentencing and Punishment of Offenders Act 2012 (ss 63-88) 22

Coroners \& Justice Act 2009 (ss 118-37 exc 135) 19

Criminal Justice and Immigration Act 2008 (ss 9,11,13,20,23,32-4)

Criminal Justice Act 1988 (ss 35-6, reviews of sentencing) 2

Criminal Justice Act 2003 (ss 142-76, 189-223,278-305) 102 [183]

Penal Servitude Act 1857 (obs) $\quad 0^{203}$

\begin{tabular}{l} 
Penal Servitude Act 1891(obs) $\quad 0^{204}$ \\
\hline
\end{tabular}

\section{(ee) Stolen Property}

Prevention of Crimes Act 1871 (ss $16 \& 19$, stolen property)

Metropolitan Police Courts Act 1839 (s 27, delivery up) ${ }^{206}$

\section{(ff) Subpoenas}

Writ of Subpoena Act 1805

\section{(gg) Terrorism (Procedural Matters)}

Suppression of Terrorism Act 1978 (ss 4-5,7-8)

Terrorism Prevention and Investigation Measures Act $2011 \quad 90$

Terrorist Asset Freezing etc Act $2000 \quad 48$

Counter-Terrorism Act 2008(ss 1-15,17-20,34,47-75,77-88,100-7,111-2) $\quad 70^{208}$ [871]

Anti-Terrorism, Crime and Security Act 2001

Terrorism Act 2000 (ss 1-10,14-23B,32-9,40-53, 63A-E) 43

Prevention of Terrorism Act 2005 (ss 1-12, control orders, appeals) 12

Terrorism Act 2006 (ss 25,28, 36) $\quad 33^{209}$ [385]

\section{(hh) Witnesses}

Criminal Procedure (Attendance of Witnesses) Act 1965 (ss 2-4) 8

Criminal Evidence Act 1898 (s 1, competency of witnesses in criminal proceedngs) 1

Criminal Evidence (Witness Anonymity) Act 2008 (ss 11-2) 2

${ }^{203}$ Ss $2 \& 6$ substitute penal servitude for transportation, as well as references to the same. They are now obsolete (penal servitude itself was obsolete in 1948).

${ }^{204} \mathrm{~S} 1$ replaces penal servitude with imprisonment, s 7 is amendment and s 11 is ST. All are now obsolete.

${ }^{205} \mathrm{~S} 16$ is the power of a constable to search for stolen property, s 19 is evidence in the case of stolen property.

${ }^{206}$ The operative section, s 27, deals with power to order delivery of goods stolen or fraudulently obtained and in possession of brokers and other dealers in second hand property. It is asserted this section is obsolete.

${ }^{207} \mathrm{~S} 55$ is spent; it refers to legislation now repealed.

${ }^{208}$ The Criminal Justice (Terrorism and Conspiracy) Act 1998 is spent; it either amends other legislation or the operative sections have been repealed.

${ }^{209}$ Relate to search and seizure (s 25), the forfeiture of terrorist publications (s 28) and the review of terrorist legislation (s 36). 
Youth Justice and Criminal Evidence Act 1999 (ss 16-39, 53-7)

Coroners \& Justice Act 2009 (ss 86-97,99,104)

Criminal Justice Adminstration Act 1914 (s 28, bigamy, witness)

Criminal Procedure Act 1865 (ss 3-8 re witnesses)

$$
\begin{aligned}
& 30^{210} \\
& 13^{211} \\
& 1 \\
& 7[62]
\end{aligned}
$$

\section{(ii) Warrants}

Criminal Procedure Act 1853 (s 9, warrant for bringing up prisoner)

Indictable Offences Act 1848 (s 13, Isle of Man warrants)

Criminal Justice Administration Act 1851(s 18, warrants)

\section{(jj) War Crimes}

War Crimes Act 1991 (s 1, jurisdiction over war crimes)

Total Sections c 2091. However, total sections would be c 1471 if terrorism (c 385 sections) and prisons (and prisoners/offenders)(c 235 sections) were placed in separate Acts. Further, Pt 2 of a Criminal Procedure Act would cover Proceeds \& Extradition (c 800 sections) leaving Pt 1 (Criminal Evidence) as c 671 sections. Note: Legislation Not Included: The Habeas Corpus Acts (1679, 1803, 1804, 1816 \& 1862) are not included since they should be reviewed separately, being antiquated with many obsolete provisions.

\section{Appendix E: Consolidating Criminal Justice Legislation}

When legislation on Criminal Procedure has been enacted, the remaining major Acts relating to criminal matters can be gathered into one Criminal Justice Act, which will consolidate all their content. Also, one Police Act.

\section{(a) Criminal Justice Act}

This Act would consolidate the residue of the following Acts:

- $\quad$ Anti-Social Behaviour Act 2003 (a) closure of premises where drugs are used unlawfully (ss 1-11); (b) parental responsibilities (18-29); (c) dispersal of groups (30-36); (d) environment (40-84);

- $\quad$ Crime and Disorder Act 1998 (a) prevention of crime and disorder (ss 1-18); (b) youth justice (ss 37-57F, inc live links, ss 57AF); (c) dealing with offenders (ss 66A-H, 86-97);

- $\quad$ Criminal Justice Act 2003;

- $\quad$ Criminal Justice Act 1987 (a) Serious Fraud Office (ss 1-3);

- Criminal Justice and Public Order Act 1994 (a) secure training orders (ss 7-150; (b) collective trespass or nuisance on land (ss 61-79); (c) cross border arrest (ss 137-40); (d) CCTV (s 163);

- Domestic Violence, Crime \& Victims Act 2004 (a) victims (ss 32-57); (b) domestic homicide reviews (s 9);

\footnotetext{
${ }^{210}$ Ss 16-33 relate to vulnerable and intimidated witnesses, ss 34-40 to the protection of witnesses from cross-examination and ss $53-7$ to the competency of witnesses and their capacity to be sworn.

${ }^{211}$ Relates to anonymity of witnesses, vulnerable and intimidated witnesses.

${ }^{212}$ Secretary of State may issue a warrant for the bringing up of a prisoner (not in custody under civil process) to give evidence.

${ }^{213} \mathrm{~S} 18$ deals with by whom warrants are to be backed in the Channel Islands.

${ }^{214} \mathrm{~S} 1$ concerns jurisdiction over war crimes.
} 
- $\quad$ Coroners \& Justice Act 2009 (a) criminal memoirs (ss 155-69);

- Violent Crime Reduction Act 2006 (a) drinking banning orders (ss 1-14);

- $\quad$ Criminal Justice and Immigration Act 2008 (a) youth rehabilitation orders (ss 1-8); (b) violent offenders orders (ss 98-117); (h) anti-social behaviour (ss 118-22); (i) special immigration status (ss 130-7). Also, s 76, reasonable force;

- $\quad$ Serious Organised Crime and Police Act 2005 (a) Serious organised crime agency (ss 1-59); (b) miscellaneous (ss 141,153-68);

- $\quad$ Criminal Justice and Court Services Act 2000 (a) national probation service (ss 5A-7,18-25); (b) dealing with offenders (ss 435); (c) access to driver licensing records (s 71);

- $\quad$ Criminal Justice (International Cooperation Act) 1990 (a) enforcement of overseas forfeiture orders (s 9); (b) rule of court (s 10); (c) offences on British ships; (d) enforcement orders (s 20); (e) jurisdiction and prosecutions (s 21);

- $\quad$ Crime (International Cooperation Act) 2003 (a) international cooperation (ss 1-51); (b) s 84 (assaults on foreign officers same as on police constables);

- $\quad$ Crime and Security Act 2010. (a) fingerprints (s 5,14-19,21-33); (b) domestic violence (ss 24-33); (c) gang related violence (ss 34-9); (d) anti-social behavior orders (ss 40-1); (e) private security industry (ss 42-4); (f) sale and supply of alcohol (s 55); searches of controlled substances (s 56);

- $\quad$ Serious Crime Act 2007 (a) serious crime prevention orders (ss 1-43); (b) encouraging or assisting crime (ss 44-67); (c) prevention of fraud (ss 68-86).

- $\quad$ Youth Justice and Criminal Evidence Act 1999

- $\quad$ Criminal Justice Act 1991 (a) power of courts to deal with offenders (ss 1-31); (b) children and young persons (ss 52-72); (d) provision of services (ss 73-92); (e) financial and other provisions (ss 93-7); (g) supplemental (ss 98-102).

- $\quad$ Access to Justice Act 1999 (a) Legal Services Commission (ss 1-26); (b) other funding of legal services (ss 27-34); (c) provision of legal services (ss 35-52); (d) appeals (ss 54-73); (e) magistrates courts (ss 74-97).

(a) Police $^{215}$

- $\quad$ Police Act 1996 (a) operation of police forces (ss1-35); (b) central supervision (ss 36-58); (c) police representative institutions (ss 59-64); (d) complaints, disciplinary proceedings (ss 54-8); (e) financial provisions (ss 92-5); (f) other matters re police (ss 96$100)$;

- $\quad$ Police Act 1997 (a) authorisation in respect of property (ss 91-108); (b) criminal record certificates (ss 112-27);

Police (Property) Act 1897 ss 1-3, relate to property in police possession;

Police Reform Act 2002 (a) complaints and misconduct (ss 9-29); (b) disciplinary proceedings (s 360); (c) police powers (ss 3860); (d) appointment of police officers etc (ss 82-103);

Police Reform and Social Responsibility Act 2011 (a) police reform (ss 1-102); (b) alcohol disorder zones and Parliament Square (ss 141-9); ${ }^{216}$

- $\quad$ Policing and Crime Act 2009 (a) criminal records (ss 93-5); (b) gang related injunctions (ss 34-50);

- $\quad$ Police \& Justice Act 2006 (a) police reform (ss 1-6); (b) powers of police (s 13); (c) crime and anti-social behaviour (ss 19-20); (b) injunctions (s 27);

- $\quad$ Police and Criminal Evidence Act 1984 (a) powers of stop and search (ss 1-7); (b) powers of entry (ss 8-23); (c) arrest (ss 2433); (d) detention (ss 34-51); (e) questioning (ss 53-65B); (f) codes of practice (ss 66-7);

- $\quad$ Criminal Justice and Police Act 2001 (a) on the spot penalties (ss1-11); (b) alcohol related disorder (ss 12-29); (c) travel restrictions on drug trafficking offenders (ss 33-7); ${ }^{217}$ (d) seizure (ss 50-70); (i) police training (ss 97-103) \& organization (ss $104-$ $7,122-8)$

Acts on Criminal Justice (including police) - 27 Acts.

\footnotetext{
215 This legislation and older legislation relating to the police (see Halsbury's Statutes, vol 35) can be contained in one Act.

${ }^{216}$ This would be better placed in Criminal Justice legislation.

${ }^{217}$ Ibid.
} 


\section{Copyrights}

Copyright for this article is retained by the author(s), with first publication rights granted to the journal.

This is an open-access article distributed under the terms and conditions of the Creative Commons Attribution license (http://creativecommons.org/licenses/by/3.0/). 